Key Words: electrolysis hydrogen nuclear

Retention:

Permanent

PHASE I SINGLE CELL ELECTROLYZER TEST RESULTS

Author: J. L. Steimke Author: T. J. Steeper

REPORT DATE: AUGUST 5, 2008

Savannah River National Laboratory

Savannah River Nuclear Solutions

Savannah River Site

Aiken, SC 29808 


\section{DISCLAIMER}

This report was prepared for the United States Department of Energy under Contract No. DE-AC09-08SR22470 and is an account of work performed under that contract. Neither the United States Department of Energy, nor SRNS, nor any of their employees makes any warranty, expressed or implied, or assumes any legal liability or responsibility for accuracy, completeness, or usefulness, of any information, apparatus, or product or process disclosed herein or represents that its use will not infringe privately owned rights. Reference herein to any specific commercial product, process, or service by trade name, trademark, name, manufacturer or otherwise does not necessarily constitute or imply endorsement, recommendation, or favoring of same by Savannah River Nuclear Solutions or by the United States Government or any agency thereof. The views and opinions of the authors expressed herein do not necessarily state or reflect those of the United States Government or any agency thereof.

Printed in the United States of America

Prepared For

U.S. Department of Energy 
Key Words: electrolysis hydrogen nuclear

Retention:

\#Permanent\#

\title{
PHASE I SINGLE CELL ELECTROLYZER TEST RESULTS
}

\author{
Author: J. L. Steimke \\ Author: T. J. Steeper
}

REPORT DATE AUGUST 5, 2008

Savannah River National Laboratory

Savannah River Nuclear Solutions

Savannah River Site

Aiken, SC 29808

Prepared for the U.S. Department of Energy Under

Contract Number DE-AC09-08SR22470

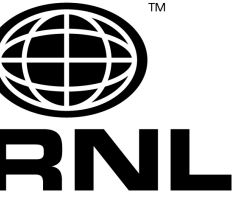




\section{TABLE OF CONTENTS}

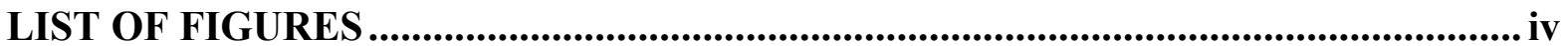

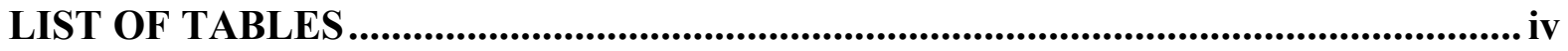

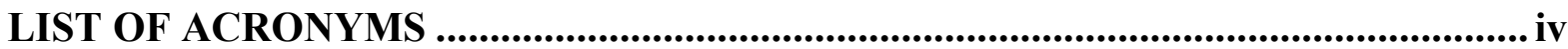

1.0 EXECUTIVE SUMMARY ......................................................................................... 1

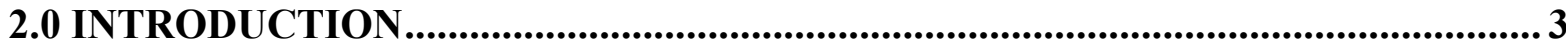

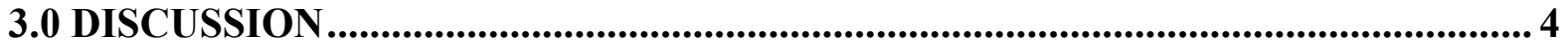

3.1 Background ...................................................................................................... 4

3.1.1 Previous Work ......................................................................................... 4

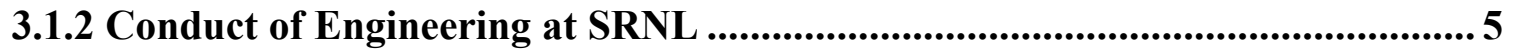

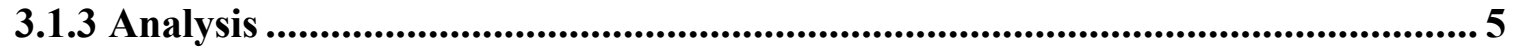

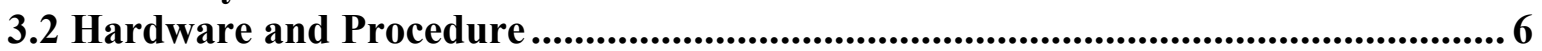

3.2.1 Overview of Test Facility ..........................................................................6

3.2.2 Apparatus.............................................................................................................. 7

3.2.2.1 Electrolyzer Cell ................................................................................................ 7

3.2.2.2 Hybrid Sulfur Electrolyzer Test Facility .................................................8 8

3.2.3 Abbreviated Procedure ................................................................................................ 1

3.2.4 Measurement of Hydrogen Production Rate....................................................... 2

3.3 Test Results ............................................................................................................... 2

3.3.1 Overview of Testing ............................................................................................ 2

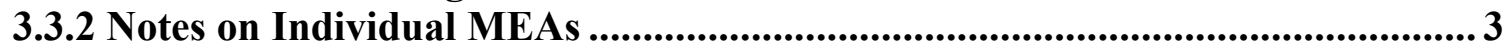

3.3.3 Electrolyzer Cell Voltages ............................................................................5

3.3.4 Anolyte Flow and Pressure Drop ................................................................ 11

3.3.5 Hydrogen Production .................................................................................................. 12

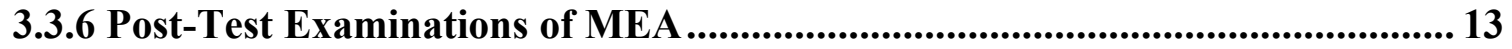

4.0 CONCLUSIONS ................................................................................................. 15

5.0 FUTURE WORK ........................................................................................ 15

6.0 ACKNOWLEDGEMENTS ....................................................................... 15

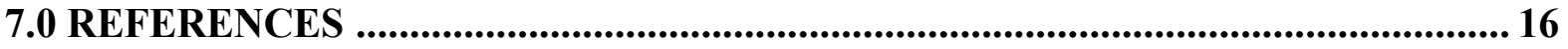




\section{LIST OF FIGURES}

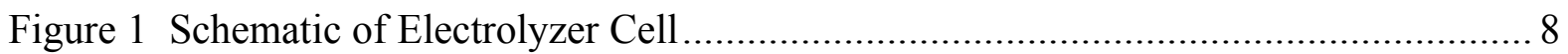

Figure 2 Schematic of Hybrid Sulfur Electrolyzer Test Facility ............................................ 9

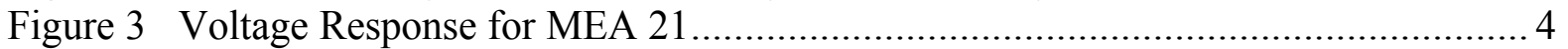

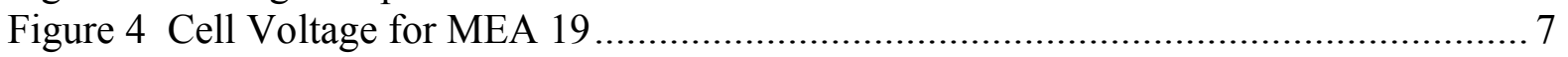

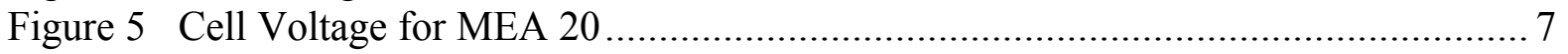

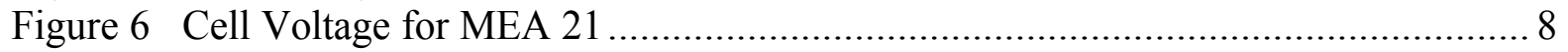

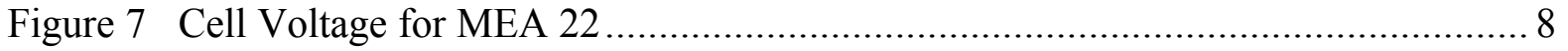

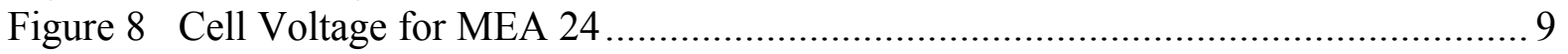

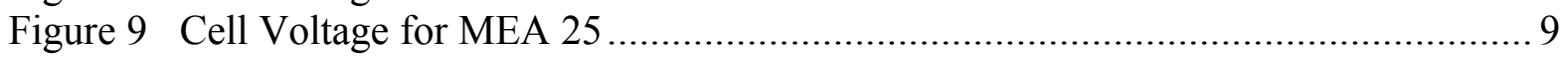

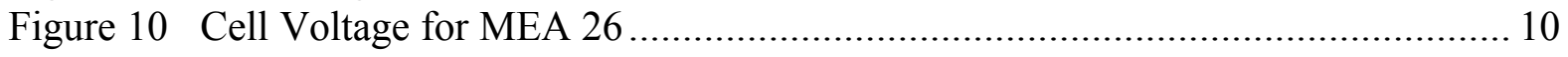

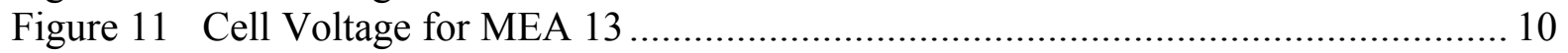

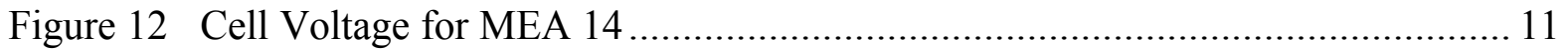

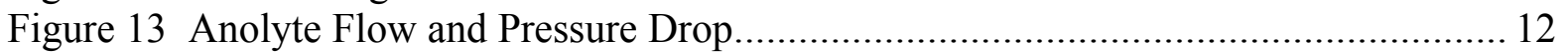

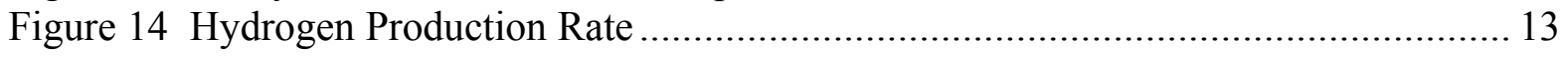

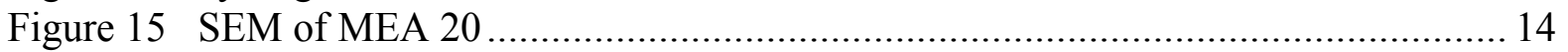

\section{LIST OF TABLES}

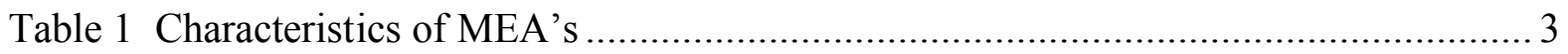

Table 2 Summary of MEA Characteristics in Single Cell Tests.......................................... 17

\section{LIST OF ACRONYMS}

$\begin{array}{ll}\text { atm } & \begin{array}{l}\text { atmospheres } \\ \text { data acquisition system }\end{array} \\ \text { DAS } & \text { Hybrid Sulfur Cycle } \\ \text { MEA } & \text { membrane electrode assembly } \\ \text { NHI } & \text { Nuclear Hydrogen Initiative } \\ \text { PEM } & \text { proton exchange membrane } \\ \text { SDE } & \mathrm{SO}_{2} \text { depolarized electrolyzer } \\ \text { SEM } & \text { Scanning Electron Microscope } \\ \text { SRNL } & \text { Savannah River National Laboratory } \\ \text { USC } & \text { University of South Carolina }\end{array}$




\subsection{EXECUTIVE SUMMARY}

This document reports the results of Phase I Single Cell testing of an $\mathrm{SO}_{2}$-Depolarized Water Electrolyzer. Testing was performed primarily during the first quarter of FY 2008 at the Savannah River National Laboratory (SRNL) using an electrolyzer cell designed and built at SRNL. Other facility hardware were also designed and built at SRNL. This test further advances this technology for which work began at SRNL in 2005. This research is valuable in achieving the ultimate goal of an economical hydrogen production process based on the Hybrid Sulfur (HyS) Cycle. The focus of this work was to conduct single cell electrolyzer tests to further develop the technology of $\mathrm{SO}_{2}$ depolarized electrolysis as part of the HyS Cycle.

The HyS Cycle is a hybrid thermochemical cycle that may be used in conjunction with advanced nuclear reactors or centralized solar receivers to produce hydrogen by water-splitting. Like all other sulfur-based cycles, HyS utilizes the high temperature thermal decomposition of sulfuric acid to produce oxygen and regenerate sulfur dioxide. The unique aspect of HyS is the generation of hydrogen in a water electrolyzer that is operated under conditions where dissolved sulfur dioxide depolarizes the anodic reaction, resulting in substantial voltage reduction. Low cell voltage is essential for both thermodynamic efficiency and hydrogen cost. Sulfur dioxide is oxidized at the anode, producing sulfuric acid that is sent to the high temperature acid decomposition portion of the cycle.

The electrolyzer cell uses the membrane electrode assembly (MEA) concept. The anode and cathode are formed by spraying platinum containing catalyst on both sides of a Proton Exchange Membrane (PEM). In most testing the material of the PEM was Nafion $\AA$. The electrolyzer cell active area can be as large as $54.8 \mathrm{~cm}^{2}$. Feed to the anode of the electrolyzer is a sulfuric acid solution containing sulfur dioxide. The partial pressure of sulfur dioxide could be varied in the range of 1 to $6 \mathrm{~atm}$ (15 to $90 \mathrm{psia}$ ). Temperatures could be controlled in the range from ambient to $80^{\circ} \mathrm{C}$. Hydrogen generated at the cathode of the cell was collected for the purpose of flow measurement and composition analysis. The test facility proved to be easy to operate, versatile, and reliable.

The primary results of Phase I of Single Cell testing follow.

1. Eight MEAs were tested in the Single Cell Facility in FY2008 during Phase I bringing the total number tested to 26 .

2. Sulfur dioxide that crosses the membrane from anode to cathode can react with a small fraction of the hydrogen gas product in a parasitic reaction to form elemental sulfur. Sulfur that flows away from the cathode with hydrogen and water is a minor nuisance and could be tolerated in a commercial scale plant. Sulfur that forms and accumulates between the membrane and cathode and delaminates the MEA is unacceptable. Formation of a sulfur layer damages the MEA and increases the path length for hydrogen ions and therefore increases cell voltage. All MEA tested in Phase I formed a sulfur layer.

3. It is important to achieve low cell voltage. Increasing current density and increasing sulfuric acid concentration in the anolyte increase the voltage. Increasing cell temperature for a given concentration of sulfur dioxide in the anolyte decreases cell voltage.

4. All else held constant, cell voltage is a nearly linear function of current density.

5. For a given temperature, concentration of the anode reactant sulfur dioxide is approximately proportional to partial pressure of $\mathrm{SO}_{2}$. Increasing temperature decreases the concentration of $\mathrm{SO}_{2}$. Having an inadequate concentration of $\mathrm{SO}_{2}$ will increase cell voltage. Having more than adequate concentration of $\mathrm{SO}_{2}$ has little or no effect on cell voltage. The adequate concentration 
of $\mathrm{SO}_{2}$ is roughly $5 \mathrm{wt} \%$. Increasing anolyte flowrate can partially compensate for an inadequate concentration of $\mathrm{SO}_{2}$.

6. Generally the lowest cell voltages are measured on the first day of testing of a new MEA. Subsequent testing typically resulted in somewhat higher voltages.

7. Degradation of cell performance as evidenced by increasing cell voltage appears to be associated with operation at higher temperature and pressure. Testing of a new MEA begins with operation at ambient conditions. If the MEA is operated only at ambient conditions on the first day, cell voltages at ambient conditions on the second day will be about the same or actually less than on the first day. If the MEA is operated at higher temperature and pressure, the cell voltages for ambient conditions will be higher on the next day of operation.

8. MEA 22, MEA 23 and MEA 24 used platinum impregnated Nafion 117 membranes. These membranes were mechanically weak and their voltage performance was poor. For MEA 22, on the second day of testing the cell voltage was high and increased with time. MEA 23 quickly shorted out. With MEA 24, the cell voltage was high on the third day of testing.

9. There was no obvious difference in performance between Nafion 115 and Nafion 117 membranes. Nafion 117 is chemically the same but thicker, 7 mils rather than 5 mils. Slightly lower voltages had been expected for the thinner membrane.

10. The catalyst was used in two forms, platinized carbon and platinum black. More platinum was required when it was in the form of platinum black, probably because the crystal size is bigger. However, with sufficient catalyst loading good cell voltage performance was achieved.

11. The best performing cell achieved a cell voltage of $660 \mathrm{mV}$ at a current density of $200 \mathrm{~mA} / \mathrm{cm}^{2}$ and $800 \mathrm{mV}$ at $500 \mathrm{~mA} / \mathrm{cm}^{2}$.

12. Within measurement uncertainty, the measured hydrogen production efficiency was $100 \%$. 


\subsection{INTRODUCTION}

HyS is conceptually the simplest of the thermochemical cycles and involves only sulfur chemistry. In the HyS Cycle hydrogen gas $\left(\mathrm{H}_{2}\right)$ is produced at the cathode of the electrochemical cell (or electrolyzer). Sulfur dioxide $\left(\mathrm{SO}_{2}\right)$ is oxidized at the anode to form sulfuric acid $\left(\mathrm{H}_{2} \mathrm{SO}_{4}\right)$ and protons $\left(\mathrm{H}^{+}\right)$as illustrated below. A separate high temperature reaction decomposes the sulfuric acid to water and sulfur dioxide which are recycled to the electrolyzers, and oxygen which is separated out as a secondary product. The electrolyzer includes a membrane that will allow hydrogen ions to pass through but block the flow of hydrogen gas. The membrane is also intended to prevent other chemical species from migrating between electrodes and undergoing undesired reactions that could poison the cathode or reduce overall process efficiency.

\section{Inputs:}

- Water

- Heat

- Electricity

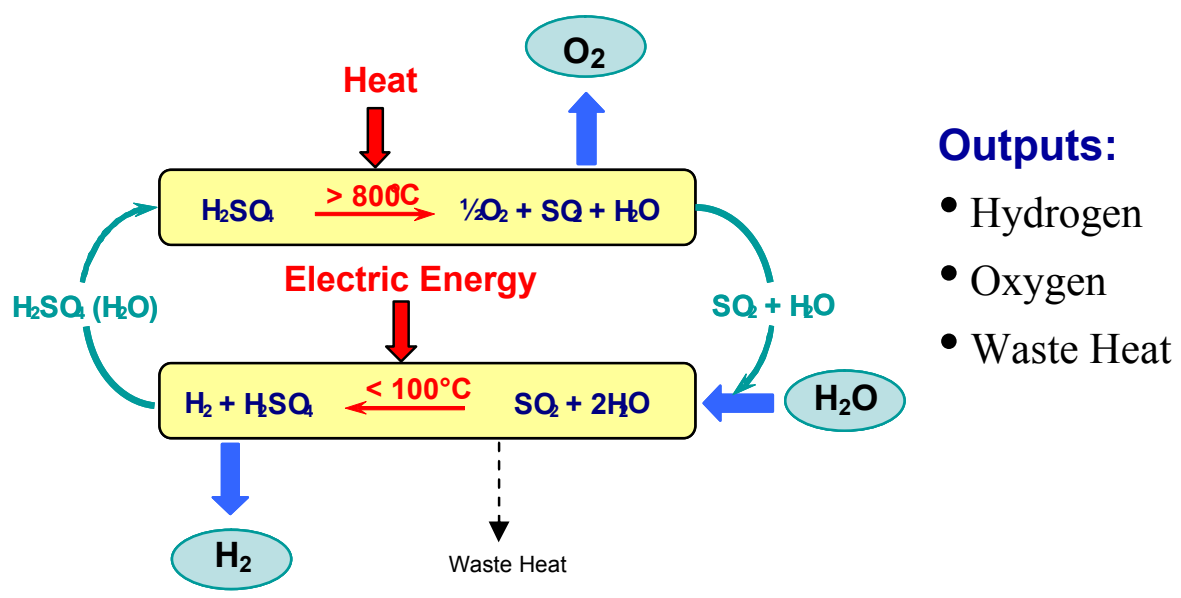

In conventional water electrolysis, water is oxidized at the anode to produce protons and oxygen. The standard cell potential for conventional water electrolysis is 1.23 volts at $25{ }^{\circ} \mathrm{C}$. However, commercial electrolyzers typically require higher voltages ranging from $1.8 \mathrm{~V}$ to $2.6 \mathrm{~V}$ [Kirk-Othmer, 1991]. The oxidation of $\mathrm{SO}_{2}$ instead of water in the $\mathrm{HyS}$ electrolyzer occurs at a much lower potential. For example, the standard cell potential for $\mathrm{SO}_{2}$ oxidation at $25^{\circ} \mathrm{C}$ in $50 \mathrm{wt} \%$ sulfuric acid is $0.29 \mathrm{~V}$ [Westinghouse, 1980]. Since power consumption by the electrolyzers is equal to voltage times current, and current is proportional to hydrogen production, a large reduction in voltage results in a large reduction in electrical power cost per unit of hydrogen generated. 


\subsection{DISCUSSION}

\subsection{BACKGROUND}

\subsubsection{Previous Work}

During the period 1975-1982, researchers at Westinghouse Electric Corporation (Farbman, 1976, Parker, 1982, Westinghouse, 1982 and Lu, 1980, 1981, 1982, 1983) tested electrochemical cells using sulfur dioxide depolarized anodes for producing hydrogen. The half-cell and overall cell reactions are:

Anode reaction

Cathode reaction

Net reaction

$$
\begin{gathered}
\mathrm{SO}_{2}(\mathrm{aq})+2 \mathrm{H}_{2} \mathrm{O}(\mathrm{aq}) \leftrightarrow \mathrm{H}_{2} \mathrm{SO}_{4}(\mathrm{aq})+2 \mathrm{H}^{+}(\mathrm{aq})+2 \mathrm{e}^{-} \\
2 \mathrm{H}^{+}(\mathrm{aq})+2 \mathrm{e}^{-} \rightarrow \mathrm{H}_{2}(\mathrm{~g}) \\
\mathrm{SO}_{2}(\mathrm{aq})+2 \mathrm{H}_{2} \mathrm{O}(\mathrm{aq}) \leftrightarrow \mathrm{H}_{2} \mathrm{SO}_{4}(\mathrm{aq})+\mathrm{H}_{2}(\mathrm{~g})
\end{gathered}
$$

They used a parallel plate cell. A porous rubber membrane was used that allowed hydraulic communication between the two parallel flow channels. A slight positive pressure difference from the catholyte to the anolyte channels was imposed to minimize $\mathrm{SO}_{2}$ crossover to the cathode while still allowing diffusion of hydronium ions (protons covalently bound to water molecules) to the cathode. The anode and cathode were made from briqueted carbon with platinum catalyst.

In the Westinghouse tests, separate liquid streams fed the electrolyzer and are referred to as the catholyte and the anolyte. The catholyte was a solution of sulfuric acid and water and the anolyte was a solution of sulfuric acid, water, and dissolved sulfur dioxide $\left(\mathrm{SO}_{2}\right)$. Sulfur dioxide was oxidized at the anode to produce sulfuric acid and protons. Thus, the outlet anolyte stream had a higher concentration of sulfuric acid than the inlet anolyte stream. The protons produced at the anode transported as hydronium ions across the porous membrane into the catholyte and were reduced at the cathode to produce hydrogen gas.

Laboratory scale tests by the Westinghouse Electric Corporation measured $\mathrm{SO}_{2}$ depolarized cell voltages ranging from 0.4 volts to 1.4 volts, depending on current density, electrode materials, and separator type. Thus, the overall power requirement of the HyS electrolyzer, which employs anodic depolarization with $\mathrm{SO}_{2}$ is much lower than for an electrolyzer employing conventional water electrolysis. Lu improved his cells and measured generally decreasing voltages during his research.

Testing by the Westinghouse Electric Company indicated that the anode overpotential decreased with increased temperature, indicating that higher electrical efficiency might occur at higher operating temperature. However, there was little or no improvement in the limiting current with increased temperature at atmospheric pressure [Lu, 1983]. The lack of improvement in the limiting current arises primarily from the reduced solubility of $\mathrm{SO}_{2}$ at the higher temperatures. To overcome the effects of reduced $\mathrm{SO}_{2}$ solubility at higher temperature, $\mathrm{Lu}$ recommended operating the electrolyzer at elevated pressure. At elevated pressure (e.g., 20 atm) the solubility of $\mathrm{SO}_{2}$ will be sufficient to allow operation at high current density and low anode overpotential to achieve increased electrical efficiencies. Lu predicted that increasing the pressure from 1 to 20 atm would reduce the anode overpotential by about $0.17 \mathrm{~V}$ [Lu, 1983]. 
Subbaiah et al. (2000) used sulfurous acid (sulfur dioxide dissolved in water) as an anode depolarizer in copper electrowinning. Electrowinning refines copper by electroplating. In the test cell the electrodes were separated by a microporous polyethylene membrane. At the anode sulfur dioxide is oxidized to sulfuric acid and at the cathode copper (II) ions are reduced to copper metal. With graphite electrodes, the addition of $40 \mathrm{~g} / \mathrm{L}$ of sulfurous acid to the anolyte reduced the cell voltage by 1.0 volt, for a current density of $20 \mathrm{~mA} / \mathrm{cm}^{2}$. The sulfuric acid product would be used in the copper refining process.

Weidner (2005) tested an alternate concept for hydrogen production using a sulfur dioxide depolarized anode. His cell used the membrane electrode assembly (MEA) concept, where the electrodes were carbon with platinum catalyst. He introduced sulfur dioxide gas at the anode and water as the catholyte. His cell potentials are approximately the same as Lu's best results. Water diffused across the Nafion ${ }^{\circledR}$ Proton Exchange Membranes (PEM) from the cathode to the anode where it reacted with sulfur dioxide to form a sulfuric acid solution, which dripped out of the cell. Hydrogen was formed at the cathode and bubbled into the water there. After a week of testing, the cell was disassembled and the cathode passages were found to be full of sulfur. Apparently, some of the sulfur dioxide crossed through the membrane where it was reduced by the hydrogen gas to elemental sulfur.

Steimke and Steeper [2005] tested two electrolyzer cells with sulfur dioxide depolarized anodes. Both cells incorporated Nafion ${ }^{\circledR}$ membranes. One cell was a commercial electrolyzer (PES) and the second cell was a research electrolyzer from University of South Carolina (USC) built from graphite. Voltages were higher than for Lu or Weidner.

Steimke and Steeper [2006] tested a graphite based electrolyzer cell designed and built at SRNL with six MEA. The cell was more durable than the 2005 cells and cell voltages were less and similar to the lowest $\mathrm{Lu}$ and Weidner voltages. The present work is a continuation of the 2006 work with some modifications to the cell and associated equipment.

Steimke and Steeper [2007] performed a 100 hour long Longevity Test in the SRNL cell. Hydrogen production efficiency was high but cell voltage slowly increased during the test.

\subsubsection{Conduct of Engineering at SRNL}

SRNL follows a formal procedure for planning and conducting all experimental work performed at the laboratory. A Task Technical and Quality Assurance Plan was written for the work documented in this report. Then all steps of Manual L1, Procedure 7.02, "Administration of Conduct of Research and Development Integrated Safety Management Hazards Assessment" were followed and documented. A formal Job Hazard Analysis was performed by committee chaired by John Steimke of SRNL. A peer reviewed Work Instruction was prepared and followed for this work. The Work Instruction specified Personal Protective Equipment for different activities. The Pressure Protection Committee analyzed those issues, made calculations and specified requirements.

\subsubsection{Analysis}

An important component of commercial development of the HyS Cycle is optimization of an electrolyzer design that features low cell fabrication cost and operates at high current density, low cell voltage and low energy consumption for pumping anolyte. Low cell cost and operation at high current density are important to limit the capital cost of the plant. Minimizing the cell voltage reduces the operating cost and increases the overall thermal efficiency of the plant. Reducing pump 
energy also reduces operating cost. Thermal efficiency is defined as the total lower heating value of the hydrogen generated divided by the total heat input, part of which goes to generate the electric power required to operate the electrolyzers. Achieving low cell cost and operation at high current density and low cell potential will involve trade-offs. For example, increased use of catalysts may reduce the cell voltage, but increases cell cost. Also, increasing current density increases cell voltage, all other conditions held constant. Increasing anolyte flowrate increases pumping cost but decreases cell voltage.

The previous work by Westinghouse utilized two-compartment electrolytic cells with various cell dividers, such as diaphragms and membranes. An objective of the SRNL work was to utilize a cell based on current PEM technology. PEM cells offer the capability for high current densities, high efficiencies and low capital costs. Considerable advancement has been made in PEM technology due to the interest in PEM fuel cells for automotive applications.

It is important to minimize the cell voltage, so it is helpful to separate the total cell voltage into five components as shown in Equation 4. Note that this test allowed the measurement of only the total cell voltage. Future electrolyzer tests will be designed with more measurements of electrical potential to separately measure the different components of voltage.

Cell voltage $\quad \mathrm{E}=\mathrm{E}_{\mathrm{rev}}+\eta_{\mathrm{a}}+\eta_{\mathrm{c}}+\eta_{\mathrm{ohm}}+\eta_{\mathrm{hw}}$

$\mathrm{E}_{\mathrm{rev}}$, reversible cell potential, is a weak function of temperature and a stronger function of acid concentration. It increases with increasing acid concentration. It is directly proportional to the free energy change for the reaction and is therefore independent of catalyst and current density.

$\eta_{\mathrm{a}}$, anode overpotential, is a function of effective surface area of catalyst, catalyst type, current density, $\mathrm{SO}_{2}$ concentration and acid concentration. It increases with increasing current density and decreases with increasing $\mathrm{SO}_{2}$ concentration. $\mathrm{SO}_{2}$ concentration is limited by the saturation concentration, which depends on temperature and pressure.

$\eta_{\mathrm{c}}$, cathode overpotential, is smaller than anode overpotential and is a function of catalyst surface area and type. It increases with increasing current density.

$\eta_{\text {ohm }}$, ohmic loss, is due to the resistance across the fluids and is proportional to current density. It can be reduced by placing anode and cathode close together.

$\eta_{\mathrm{hw}}$, hardware loss, is proportional to current density. It can be reduced by careful hardware design and material selection.

\subsection{HARDWARE AND PROCEDURE}

\subsubsection{Overview of Test Facility}

A test facility capable of testing sulfur dioxide depolarized electrolyzers at pressures up to 6 atm and temperatures up to $80^{\circ} \mathrm{C}$ was designed and constructed. The facility is capable of operating with electrolyzer currents up to 50 amperes or a current density of $1000 \mathrm{~mA} / \mathrm{cm}^{2}$ for a cell area of $50 \mathrm{~cm}^{2}$. A current of 50 amperes is sufficient to generate approximately 20 liters per hour of hydrogen. The test facility proved to be versatile and easy to use. The MEA and flowfields inside the electrolyzer 
cell were easily replaced. The data acquisition system (DAS) computer controlled anolyte flowrate, even with changing hydraulic resistance. Computer interlocks were easily added. It was relatively easy to change liquids, flush both sides of the cell and isolate part of the piping. The accurate measurement of hydrogen generated helped to explain other observations and to quantify the amount of hydrogen that reacted with sulfur dioxide. Sulfur could be flushed with water from the cathode side of the cell and collected. The DAS has additional voltage inputs available for use with future cells with provisions to measure individual components of the overall cell voltage. For the current work only the total cell potential and the power supply voltage were measured.

\subsubsection{Apparatus}

\subsubsection{Electrolyzer Cell}

Figure 1 shows a schematic of the electrolyzer cell. The heart of the electrolyzer is a membrane electrode assembly (MEA) consisting a Proton Exchange Membrane and an anode and cathode sprayed on the two sides of it. Anolyte containing the reactants water and sulfur dioxide is pumped past the anode. Hydrated hydrogen ions cross the membrane from the anode to the cathode where the chemical reaction of equation 2 occurs and hydrogen gas is generated. Hydrogen gas can not cross the membrane. Water is introduced to the cathode. Depending on conditions there can be a net flux of water in either direction. Electro-osmotic drag transports water from anode to cathode. The concentration gradient of water tends to transport water in the opposite direction. Sulfur dioxide can diffuse across the membrane from anode to cathode where it can be reduced by hydrogen to elemental sulfur or hydrogen sulfide.

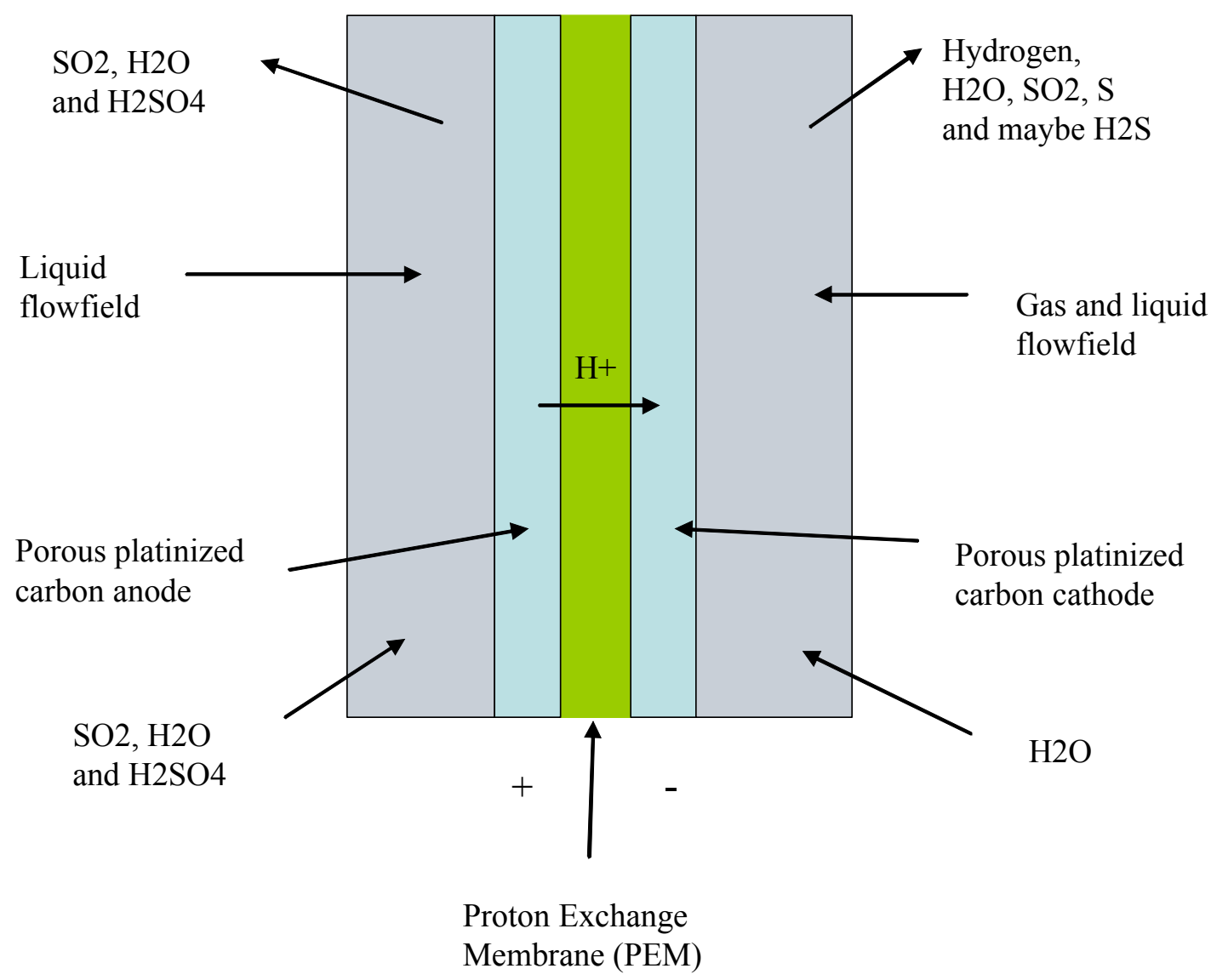


Figure 1 Schematic of Electrolyzer Cell

\subsubsection{Hybrid Sulfur Electrolyzer Test Facility}

Figure 2 is a schematic of the equipment in the facility, which was located in a chemical hood. Air flow was maintained whenever hydrogen or sulfur dioxide was present in the hood. There were two separate systems, the anode side system and the cathode side system. Anolyte accumulated in the Anolyte Reservoir and was pumped through a flowmeter to the anode side of the cell. Anolyte exiting the cell returned to the top of the Anolyte Tank where it contacted sulfur dioxide gas in the packed bed. Sulfur dioxide was provided from an inverted $100 \mathrm{lb}$ cylinder. A syringe pump was used to meter liquid $\mathrm{SO}_{2}$. A backpressure regulator prevented vaporization of the $\mathrm{SO}_{2}$ inside the pump. Another syringe pump was used to meter water to the Anolyte Tank. If there was air inside the Anolyte Tank, the vent was left open while an excess of $\mathrm{SO}_{2}$ was added. Thereafter, the vent was closed. The rate of $\mathrm{SO}_{2}$ addition controlled the pressure.

The cathode side system included a water flush to the cathode. This helped to hydrate the membrane and flush away any elemental sulfur formed. The mixture of water, hydrogen and sometimes sulfur entered the Sulfur Collector. Hydrogen flowed on through a backpressure regulator to the Hydrogen Collector. The gas displaced water which was weighed on a scale. Pressure was monitored at the top of the Hydrogen Collector. Pressures at the anode and cathode were controlled to be equal.

Power was supplied to the electrolyzer with a DC power supply. The power supply was usually operated in current control mode, but could also be operated in voltage control mode.

Instrumentation included four pressure transducers and six thermocouples. Data were recorded by a Data Acquisition System. Observations were recorded in a laboratory notebook. 


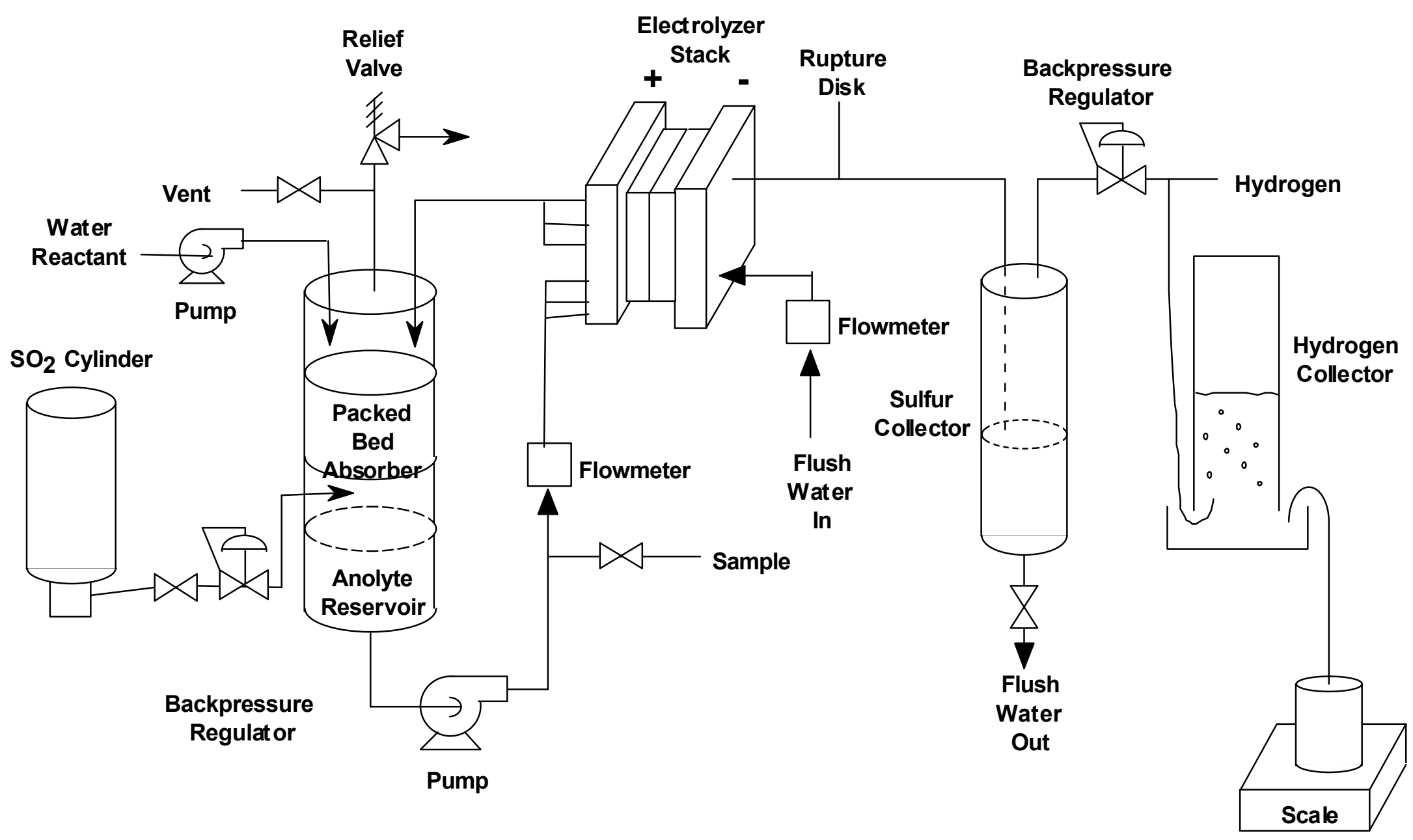

Figure 2 Schematic of Hybrid Sulfur Electrolyzer Test Facility 


\subsubsection{Abbreviated Procedure}

The testing of a new MEA began with its installation in the cell, which was then hydrostatically tested. The cell was installed in the facility followed by a leak test. A day of testing always began at ambient conditions and the anolyte was saturated with $\mathrm{SO}_{2}$ at one atm of partial pressure and $20^{\circ} \mathrm{C}$. Any air in the Anolyte Tank was purged. A range of current densities was run. The anolyte was periodically sampled and the density was measured. The flowrate of dilution water added to the anolyte was adjusted to maintain acid concentration. Almost all testing reported here was for $30 \mathrm{wt} \%$ sulfuric acid in the anolyte. If there was sufficient time, cell temperature and anolyte pressure were increased to $80^{\circ} \mathrm{C}$ and four to six atmospheres pressure. Pressure was controlled by the rate of $\mathrm{SO}_{2}$ addition. The anolyte flowrate was usually $80 \mathrm{~mL} / \mathrm{min}$. The deionized water flowrate to the cathode was about $9 \mathrm{ml} / \mathrm{min}$. At the end of each day of testing, the anode side of the cell and also the anolyte pump were rinsed four times with deionized water and were left overnight soaking in water. The purpose of rinsing the pump was to reduce or eliminate corrosion. The cathode side of the cell was filled with deionized water and left soaking in it.

The following steps were taken periodically during the test.

1. Samples of anolyte were collected at the sample point shown on Figure 2 and density was measured. If density was less than the target of $1.22 \mathrm{~g} / \mathrm{mL}$ the rate of water addition was reduced and vice versa.

2. Anolyte pressure was monitored. If the pressure was less than the target pressure the rate of $\mathrm{SO}_{2}$ addition was increased and vice versa.

3. The inventories of $\mathrm{SO}_{2}$ syringe pump and the water syringe pump were monitored and the pumps were refilled when nearly empty.

4. The Hydrogen Collector was recharged with water when it became nearly full of hydrogen.

5. The Sulfur Collector level was controlled either by partial periodic draining or slow continuous discharge.

6. Excess anolyte was removed, either in batches and later continuously.

Two people were always in the laboratory during testing. Hood ventilation was used whenever the Absorber contained sulfur dioxide or if hydrogen was being generated or stored in the Hydrogen Collector. After the cell containing an MEA was installed in the loop, air was used to pressurize to 3 psig, then valved off. A decrease in pressure indicated a leak, which was repaired. A liter of the desired acid solution was mixed in a bottle. The valve between the Anolyte Tank and pump suction was closed and another valve at pump suction was opened. The tube attached to this valve was inserted into the bottle of acid solution. The pump was used to draw the acid into the Absorber. The Anolyte Tank exit valve was opened and the other valve was closed. The Anolyte Pump was started and acid solution was circulated through the cell and Anolyte Tank at a flowrate of $80 \mathrm{~mL} / \mathrm{min}$.

The sulfur dioxide piston pump was charged with sulfur dioxide from a $100 \mathrm{lb}$. gas cylinder. This transfer worked best if a heat gun was used to warm the cylinder for five minutes previous to the transfer. This heating increased the cylinder pressure by about 10 psi. Otherwise most of the volume in the cylinder was occupied by vapor. The piston pump was deadheaded until a fast pressure increase was observed to eliminate any vapor pocket. Then, liquid sulfur dioxide was pumped into the Absorber at an initial rate of $5 \mathrm{~mL} / \mathrm{min}$ to allow the anolyte to saturate. During saturation the Absorber was vented to atmosphere through the vent shown in Figure 2. The liquid sulfur dioxide instantly flashed to vapor. After about 20 minutes the sulfur dioxide flow was reduced to match the rate of consumption by the electrolyzer. 
To achieve higher temperature operation, a 400 watt heater was imbedded in the thick stainless steel anode backing plate and another in the cathode backing plate. Also, a Thermo Haake DC30 bath heater set at $80^{\circ} \mathrm{C}$ was used to circulate hot water through the inner annulus surrounding the Anolyte Tank. Temperatures were measured using thermocouples inserted in the Anolyte Tank, the anode non-porous graphite plate and in the cathode graphite plate. Temperature was manually controlled using auto-transformers. A thermocouple on the cathode side of the cell controlled the high temperature shutdown circuit, which was set at $80^{\circ} \mathrm{C}$ and which protected the Teflon tubing from over heating. If the temperature reached $80^{\circ} \mathrm{C}$, electrical relays in the shutdown circuit opened to deenergize the two electrolyzer heaters.

\subsubsection{Measurement of Hydrogen Production Rate}

The SRNL Facility measured hydrogen flowrates by displacement of water from a cylinder to allow identification of any discrepancy from the theoretical rate. Hydrogen flowrates were computed in two ways. The first method used the pressure transducer at the top of the cylinder, which was calibrated in psig, to indicate the height of water. Initially, the Hydrogen Collector has a sub-atmospheric pressure, about -2 psig. As water is displaced by hydrogen the water level drops, and the pressure approaches atmospheric pressure. The volume was adjusted for temperature and pressure inside the collector. The second method was to weigh the water displaced from the column. The density of water was used to compute the volume of hydrogen. This volume was also adjusted for temperature and pressure.

\subsection{TEST RESULTS}

\subsubsection{Overview of Testing}

SRNL continued single cell electrolyzer testing during the First Quarter of FY08. Eight MEA's were tested, with the primary objective of providing a better understanding of the design and operating conditions that affect the formation of a sulfur layer inside the cell MEA.

The test facility pump problems experienced at the end of FY07 were addressed and satisfactorily solved. The pump problems had limited test duration and had resulted in pressure upsets, potentially damaging the MEA in the test electrolyzer. The syringe pump that feeds liquid $\mathrm{SO}_{2}$ to the $\mathrm{Absorber}$ was repaired, the motor and piston seal were replaced. Also, the Teflon gear pump used for anolyte feed supply was replaced with a similar pump made from Carpenter Alloy 20. It was determined that eighteen months of operation had worn the Teflon gears and significantly reduced the pump's performance. Operation of the Alloy 20 pump is much better and has solved the vapor-lock problems that were experienced with the worn Teflon pump. Vapor lock occurred when the pump sped up in an attempt to maintain flow, but the increase in pump rpm caused more $\mathrm{SO}_{2}$ vapor to come out of solution and stopped pumping action.

The characteristics of the various MEA's tested during First Quarter FY08 as well as some previous MEAs are shown in Table 1. The characteristics of all MEA's tested during the last three years are listed in Table 2, which is attached at the end of this report. The thicknesses of Nafion 115 and Nafion 117 are 5 mils and 7 mils, respectively. All tests used a carbon paper diffusion layer (7 mils thick) next to the anode and a carbon cloth diffusion layer (12 mils thick) next to the cathode.

The testing of a new MEA began with its installation in the cell, which was then hydrostatically tested. The cell was installed in the facility followed by an additional leak test. A day of testing always began at ambient conditions and the anolyte was saturated with $\mathrm{SO}_{2}$ at one atm of partial 
pressure and $20^{\circ} \mathrm{C}$. Any air in the Absorber was purged. A range of current densities was run. The anolyte was periodically sampled and the density was measured. The flowrate of dilution water added to the anolyte was adjusted to maintain acid concentration. Almost all testing reported here was for a $30 \mathrm{wt} \%$ sulfuric acid in the anolyte. If there was sufficient time, cell temperature and anolyte pressure were increased to $80^{\circ} \mathrm{C}$ and four to six atmospheres pressure. At the end of each day of testing, the anode side of the cell and also the anolyte pump were rinsed four times with deionized water and were left overnight soaking in water. The purpose of rinsing the pump was to reduce or eliminate corrosion. The cathode side of the cell was filled with deionized water and left soaking in it.

\section{Table 1 Characteristics of MEA's}

\begin{tabular}{|c|c|c|c|c|c|c|c|c|c|}
\hline MEA & Membrane & $\begin{array}{l}\text { Anode } \\
\text { Catalyst }\end{array}$ & $\begin{array}{l}\text { Cathode } \\
\text { Catalyst }\end{array}$ & $\begin{array}{l}\text { Anode } \\
\mathrm{Pt}, \\
\mathrm{mg} / \mathrm{cm} 2\end{array}$ & $\begin{array}{l}\text { Cathode } \\
\mathrm{Pt} \text {, } \\
\mathrm{mg} / \mathrm{cm} 2\end{array}$ & $\begin{array}{l}V_{0} \\
\text { amb. }\end{array}$ & $\begin{array}{l}R \\
\text { amb. } \\
\Omega \mathrm{cm}^{2}\end{array}$ & $\begin{array}{l}\mathrm{V}_{\mathbf{0}} \\
80^{\circ} \mathrm{C}\end{array}$ & $\begin{array}{l}\mathrm{R} \\
80^{\circ} \mathrm{C} \\
\Omega \mathrm{cm}^{2} \\
\end{array}$ \\
\hline 4 & Nafion 117 & Pt-C & Pt-C & 0.88 & 0.99 & 0.62 & 1.03 & $0.57^{*}$ & $0.65^{*}$ \\
\hline 9 & Nafion 117 & Pt-Black & Pt-Black & 4.0 & 4.0 & 0.66 & 0.80 & na & na \\
\hline 11 & Nafion 115 & Pt-C & Pt-C & 1.09 & 0.72 & 0.66 & 0.83 & 0.55 & 0.44 \\
\hline 12 & Nafion 115 & Pt-C & Pt-C & 1.01 & 1.01 & 0.58 & 0.76 & na & na \\
\hline 14 & Nafion 117 & Pt-C & Pt-C & 0.8 & 0.8 & 0.63 & 0.86 & 0.58 & 0.42 \\
\hline 19 & Nafion 115 & Pt-C & $\mathrm{Pt}-\mathrm{C}$ & 0.83 & 0.70 & 0.62 & 0.67 & 0.55 & 0.80 \\
\hline 20 & Nafion 115 & Pt-C & Pt-Black & 0.782 & 2.67 & 0.65 & 1.62 & 0.58 & 0.74 \\
\hline 21 & Nafion 115 & Pt-C & Pt-Black & 0.6 & 2.9 & 0.70 & 2.04 & $0.66^{* *}$ & $0.98 * *$ \\
\hline 22 & $\begin{array}{l}\text { Pt-treated } \\
\text { Nafion } 117\end{array}$ & Pt-Black & Pt-Black & 1.0 & 1.0 & na & na & 0.66 & 3.0 \\
\hline 23 & $\begin{array}{l}\text { Pt-treated } \\
\text { Nafion } 117\end{array}$ & Pt-C & Pt-Black & 1.0 & 1.0 & na & na & na & na \\
\hline 24 & $\begin{array}{l}\text { Pt-treated } \\
\text { Nafion } 117\end{array}$ & Pt-C & Pt-Black & 1.0 & 1.0 & 0.64 & 0.69 & 0.58 & 0.55 \\
\hline 25 & Nafion 117 & Pt-Black & Pt-Black & 4.0 & 4.0 & 0.62 & 0.79 & 0.58 & 0.46 \\
\hline 26 & Nafion 117 & Pt-Black & Pt-Black & 4.0 & 4.0 & 0.60 & 0.81 & 0.58 & 0.50 \\
\hline
\end{tabular}

\subsubsection{Notes on Individual MEAs}

MEA 19 was a conventional design, where both anode and cathode were platinized carbon. Testing of MEA 19 started on September 18, 2007. On the first day of testing a range of current densities was run at ambient conditions and $30 \mathrm{wt} \%$ acid strength in the anolyte. During heatup, the anolyte pump stopped functioning, interrupting the test when the cell temperature reached $58^{\circ} \mathrm{C}$. Testing of MEA 19 resumed on September 19 and 20 and October 3, but operational problems limited the temperature to $30^{\circ} \mathrm{C}$. On October $17 \mathrm{MEA} 19$ was tested to $5 \mathrm{~atm}$ and $80^{\circ} \mathrm{C}$. The anolyte pump was disassembled and some bits of trash were found inside it.

MEA 20 was like MEA 19, except that the cathode was made from platinum black, because there was some evidence that this might help prevent the formation of a sulfur layer. MEA 20 Testing of MEA 20 began on October 22 with operation at both ambient conditions and $5 \mathrm{~atm}$ and $80^{\circ} \mathrm{C}$. Testing resumed on October 23. The target conditions of $5 \mathrm{~atm}$ and $80^{\circ} \mathrm{C}$ were attained, but shortly thereafter the seal on the syringe pump that supplies sulfur dioxide to the anolyte tank failed and pressure decreased. On October 31 the Anolyte Pump was rebuilt in an effort to improve its performance. On 
November 11 sulfur dioxide was added manually without the use of the syringe pump. Sulfur dioxide was added from the cylinder to achieve a pressure of $22 \mathrm{psig}$. The cell and Anolyte Tank were heated which increased the pressure to as much as $59 \mathrm{psig}$. Then, pressure decreased as sulfur dioxide was consumed. The temperature was held at $80^{\circ} \mathrm{C}$. The cell voltage was relatively high, so the decision was made to stop testing. A new syringe pump seal was installed. However, when the syringe was used with sulfur dioxide, it again leaked past the piston seal.

MEA 21 was similar to MEA 20. Testing of MEA 21 began on November 19 and sulfur dioxide was added in manual mode. A temperature of $63^{\circ} \mathrm{C}$ was achieved, however, one of the heaters installed in the cell failed and no higher temperature could be achieved. The failed heater was replaced and testing resumed on November 28. Testing resumed on November 28 and $6 \mathrm{~atm}$ and $80^{\circ} \mathrm{C}$ were achieved. Cell voltages were relatively high, so testing stopped. Even though MEA 21 was nominally identical to MEA 20, its performance was considerably worse. Preparation of a Pt-Black cathode, as used in these two MEA's, is much more difficult and requires higher temperatures than preparation of Pt-Carbon electrodes. As a result, we continue to refine our fabrication methods to optimize the catalyze formation.

During MEA 21 testing, it was observed that the cell voltage responded much slower to changes in current than was the case with previous MEA's. This can be seen in Figure 3. For example, the transition at 4.2 hours required 12 minutes. With most previous MEA's, five minutes of transition was adequate. Also, there was a pronounced overshoot in voltage. These characteristics are likely the result of low porosity of the anode. Although MEA 21 had a Pt-carbon anode, it was subjected to different processing conditions during fabrication than previous Pt-carbon anodes due to the methods used for the Pt-black cathode preparation.

\section{Cell Voltage and Current for MEA 21}

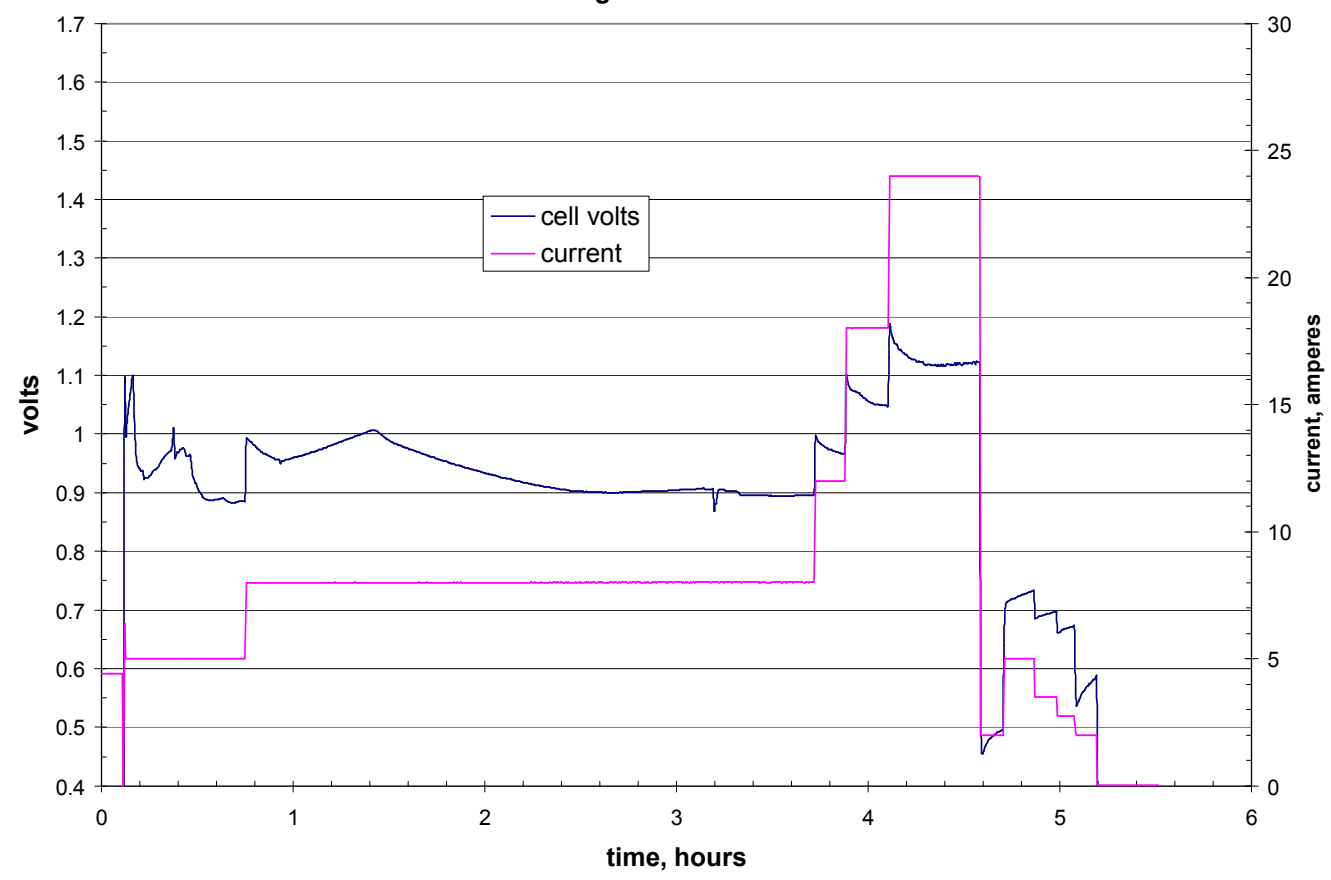

Figure 3 Voltage Response for MEA 21 
MEA's 22, 23, 24, and 25 were fabricated by Giner Electrochemical. They each used a Pt-black cathode (similar to MEA 9). MEA 22 and MEA 25 also had a Pt-black anode, whereas MEA 23 and MEA 24 had platinized carbon anodes. Platinized carbon anodes are expected to provide better voltage performance with the same catalyst loading than platinum black anodes, due to a much higher catalyst surface area. MEA's 22, 23, and 24 used a platinum treated membrane, whereas MEA 25 had an untreated Nafion 117 membrane.

Testing of MEA 22 started on December 4 with operation at ambient conditions and as high as $80^{\circ} \mathrm{C}$ and $6 \mathrm{~atm}$. At one point the DC power supply was inadvertently unplugged. Minutes later a dense sulfur cloud formed in the Sulfur Collector. Testing resumed on December 5. The cell voltage for low current at ambient conditions was very high and increasing so testing was terminated.

Testing of MEA 23 started on December 10. The cell had shorted as evidenced by no hydrogen production. The cell was disassembled, cleaned and rebuilt. The cell was still shorted, so testing stopped. There were no usable data for MEA 23.

Testing of MEA 24 began on December 12. Cell voltages for ambient conditions were typical. When the cell was heated to $45^{\circ} \mathrm{C}$, cell voltages became erratic and much off-gasing was observed in the anolyte discharge from the cell. Testing stopped for the day. The cell was disassembled, cleaned and reassembled. Testing resumed on December 12 for both ambient conditions and as much as 4 atm and $80^{\circ} \mathrm{C}$. Testing resumed on December 17. Cell voltages for ambient conditions were about 150 mv higher than the original ambient voltages. The temperature and pressure were increased to as much as $5 \mathrm{~atm}$ and $66 \mathrm{C}$.

Testing of MEA 25 began on December 27 with ambient operation. MEA 25 was intended to be the same as MEA 9, which had not developed a sulfur layer. On December 28 and December 31 the cell was operated at ambient conditions and up to $80^{\circ} \mathrm{C}$ and five atm. On January 2 the maximum temperature and pressure were $36 \mathrm{C}$ and four atm. Testing of MEA 25 was terminated because the voltage was increasing with time and the anolyte pressure drop was high, $17 \mathrm{psid}$. On the first day of testing the pressure drop had been 4 psid.

MEA 26 was nominally the same as MEA 25. It was intended to operate MEA 26 for the same length of time as MEA 9. Testing of MEA 26 began on January 9 with ambient operation. On January 11 it was operated at ambient conditions and up to $80^{\circ} \mathrm{C}$ and four atm. On January 15 it was operated for 30 minutes at ambient conditions.

\subsubsection{Electrolyzer Cell Voltages}

Cell voltage is a function of MEA characteristics, any sulfur formation inside the MEA, anolyte concentration expressed as weight percent sulfuric acid, cell temperature, concentration of sulfur dioxide in the anolyte and current density. Concentration of sulfur dioxide is approximately proportional to partial pressure of sulfur dioxide in the gas space of the Absorber. With sufficient concentration of sulfur dioxide, further increases in concentration have little or no effect on cell voltage. Testing of MEA 19 through MEA 26 was conducted with sufficient concentration. Holding all else constant, the relationship between current density and cell voltage has the following form, where $\mathrm{I} / \mathrm{A}$ is current density.

$\mathrm{V}_{\text {cell }}=\mathrm{V}_{0}+\mathrm{R} \mathrm{I} / \mathrm{A}$

This relationship breaks down for very low and very high current densities. The term $\mathrm{V}_{0}$ is somewhat dependent on temperature, increasing temperature from $20^{\circ} \mathrm{C}$ to $80^{\circ} \mathrm{C}$ decreases that term by about 50 $\mathrm{mV}$. Adding a sulfur layer to the MEA or increasing acid concentration increases the term $\mathrm{R}$ and can 
more than double it. Increasing cell temperature decreases the term $\mathrm{R}$. The best cell performance has been on the first day or two of testing and degrades thereafter. Table 1 lists initial values of $V_{0}$ and $R$ for some MEA. We think the reason is sulfur accumulation inside the MEA.

The best initial voltage performance at ambient conditions has been

$\mathrm{V}_{\text {cell }}=0.62$ volt $+0.67 \mathrm{ohm} \mathrm{cm}^{2} \mathrm{I} / \mathrm{A}$

The best initial voltage performance at $80^{\circ} \mathrm{C}$ and four to six atm has been

$\mathrm{V}_{\text {cell }}=0.58$ volt $+0.42 \mathrm{ohm} \mathrm{cm}^{2} \mathrm{I} / \mathrm{A}$

Table 1 lists some initial values of $\mathrm{V}_{0}$ and $\mathrm{R}$ for some MEA.

Cell voltages for MEA 19 through MEA 22, and MEA 24 through MEA 26 are shown in Figures 4 through 10. In addition voltages for MEA 13 and 14 are plotted in Figures 11 and 12. The best historical elevated temperature and pressure performance (MEA 14) is plotted as a red line. The best historical ambient performance (MEA 19) is plotted as a blue line.

Figure 4 shows that MEA 19 had excellent ambient performance on the first day of testing. Elevated temperature and pressure testing was conducted later the first day. The following day and subsequent days the ambient performance degraded.

Figure 5 shows that MEA 20 had generally poor performance. Elevated temperature and pressure were used on three days of testing. Cell voltage increased each day.

Figure 6 shows that MEA 21 was also a poor performer. A dense cloud of sulfur was observed in the Sulfur Collector for very low current densities, but not for higher currents.

Figure 8 shows that MEA 22 was also a poor performer. During the second day of testing, after running at elevated temperature and pressure the first day, the voltage for ambient conditions greatly increased.

Figure 9 shows that MEA 24 was initially a good performer. On the first day of testing only ambient conditions were run. Ambient temperature voltages on the second day were almost the same. On the third day of testing, ambient voltages were much higher.

MEA 25, shown in Figure 10, was run the first day at ambient conditions only. Cell voltages were high. On the second day, ambient voltages and elevated temperature and pressure voltages were low, near historical best. But on subsequent days, voltages increased for both ambient and elevated conditions.

MEA 26 displayed the same pattern as MEA 25. It was operated only at ambient conditions the first day. The second day voltages for both ambient and elevated were excellent. On the third day the ambient voltage greatly increased.

Figure 12 shows only ambient temperature voltages for MEA 13. On the first two days of testing only ambient conditions were run. On the third day of testing the MEA was run at ambient and then elevated temperature and pressure. The ambient voltages for the first three days were about the same. On the fourth day, after operation at elevated temperature and pressure, the cell voltage increased.

Figure 13 shows that MEA 14 displayed generally increasing cell voltages. 


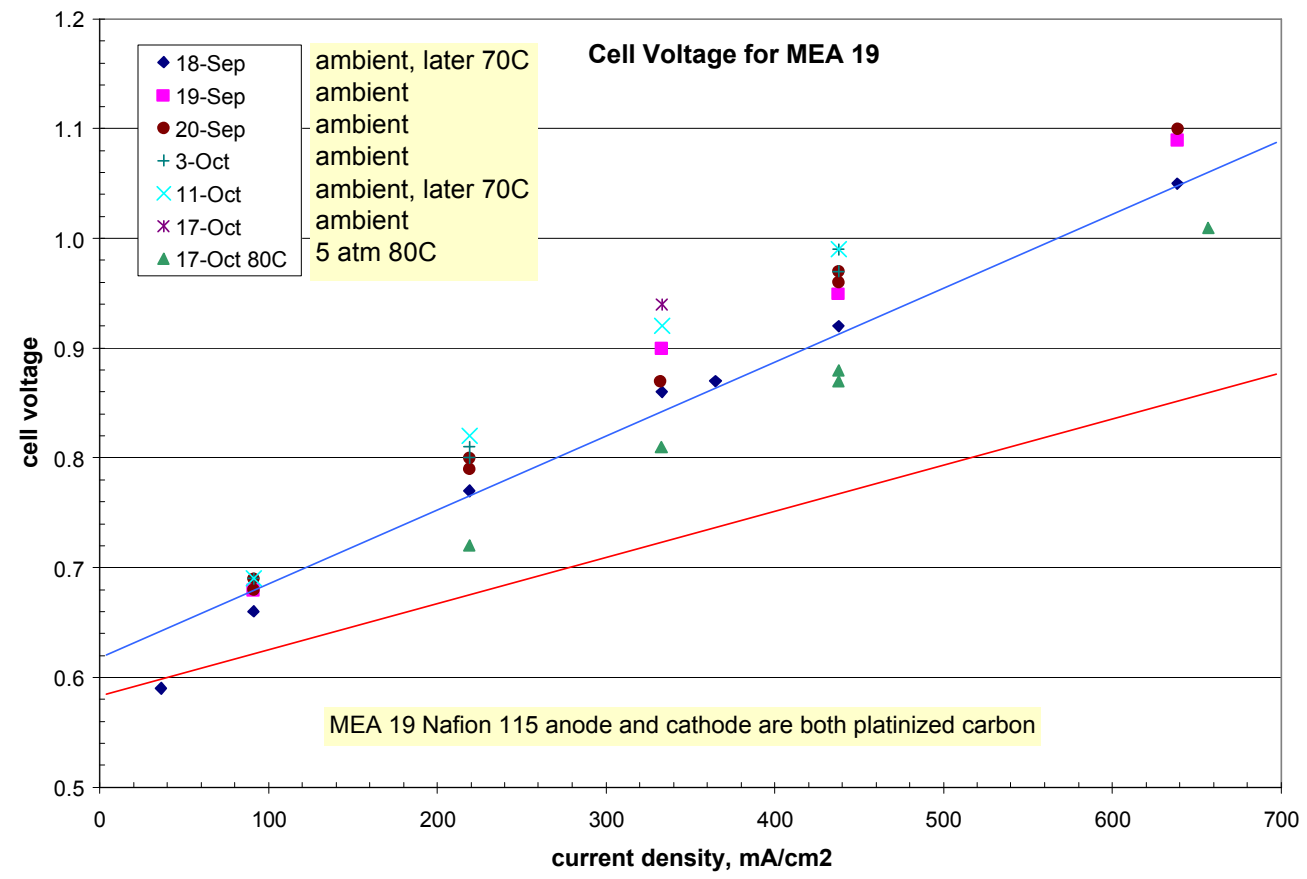

Figure 4 Cell Voltage for MEA 19

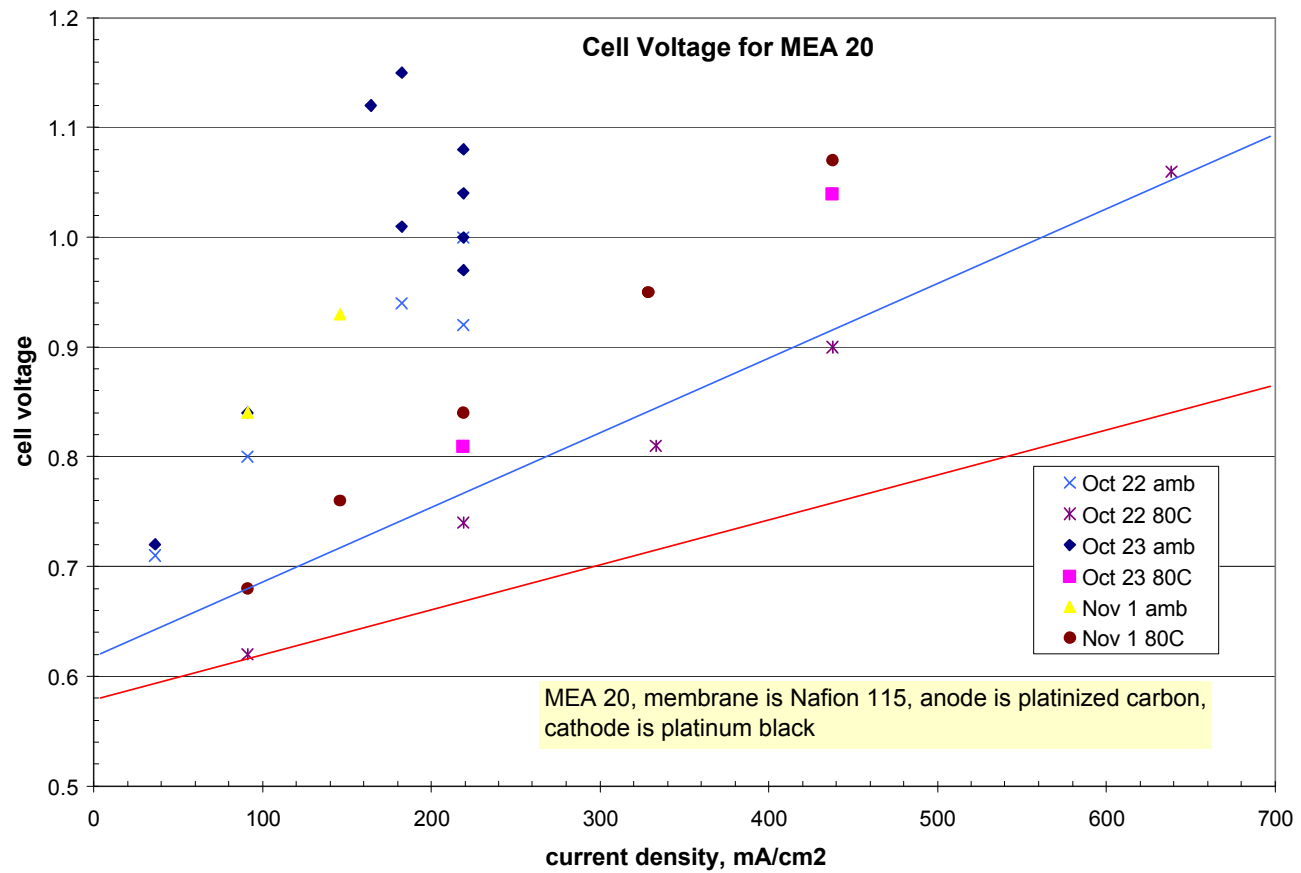

Figure 5 Cell Voltage for MEA 20 


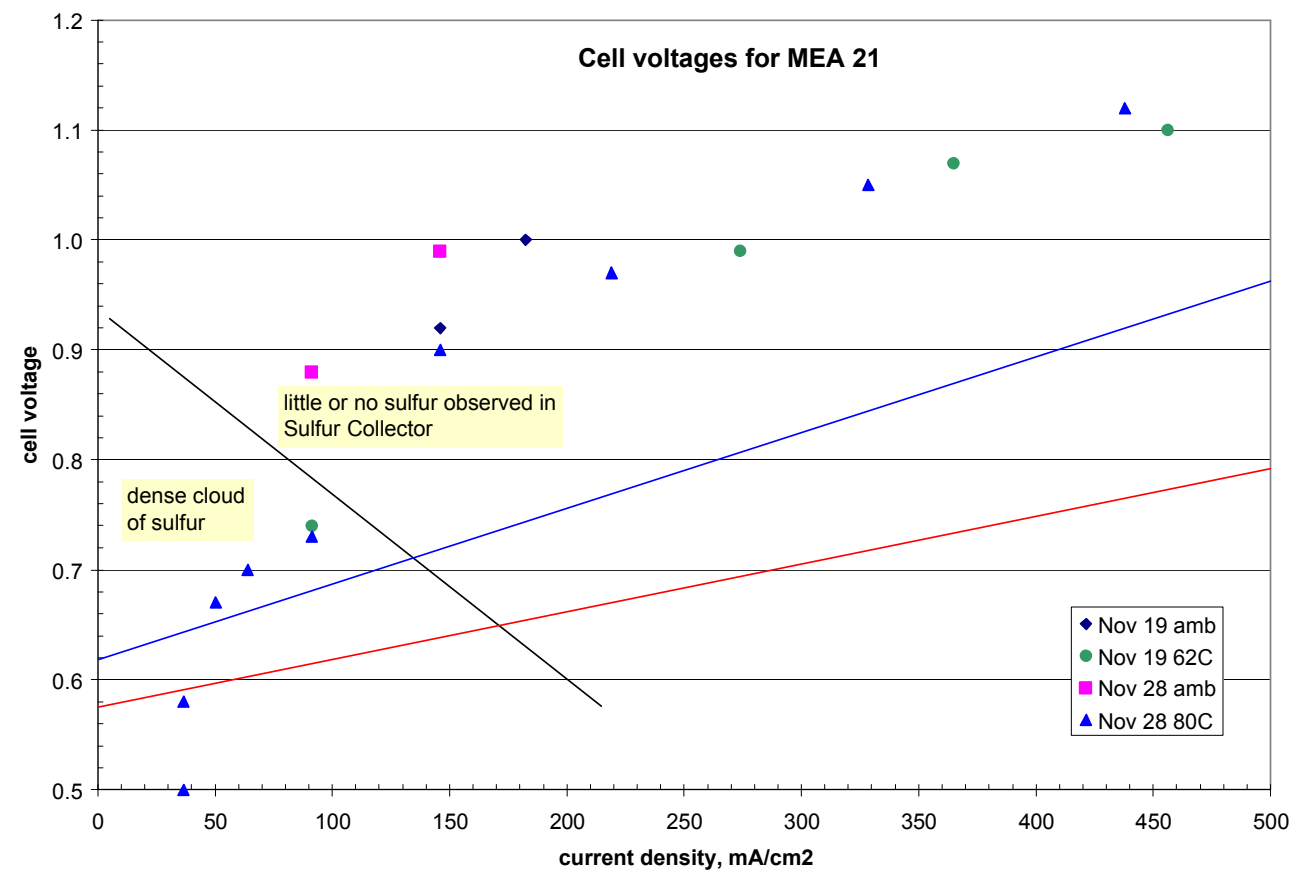

Figure 6 Cell Voltage for MEA 21

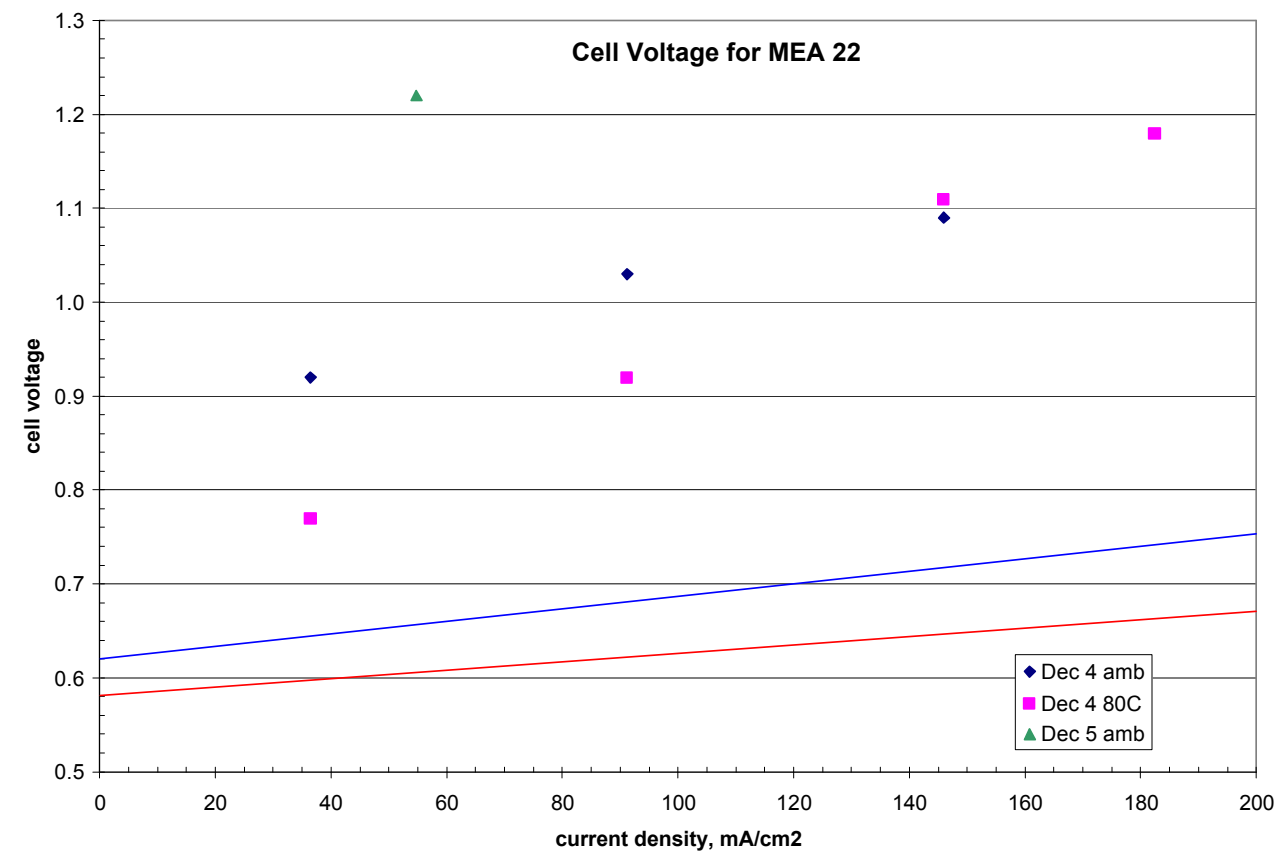

Figure 7 Cell Voltage for MEA 22 


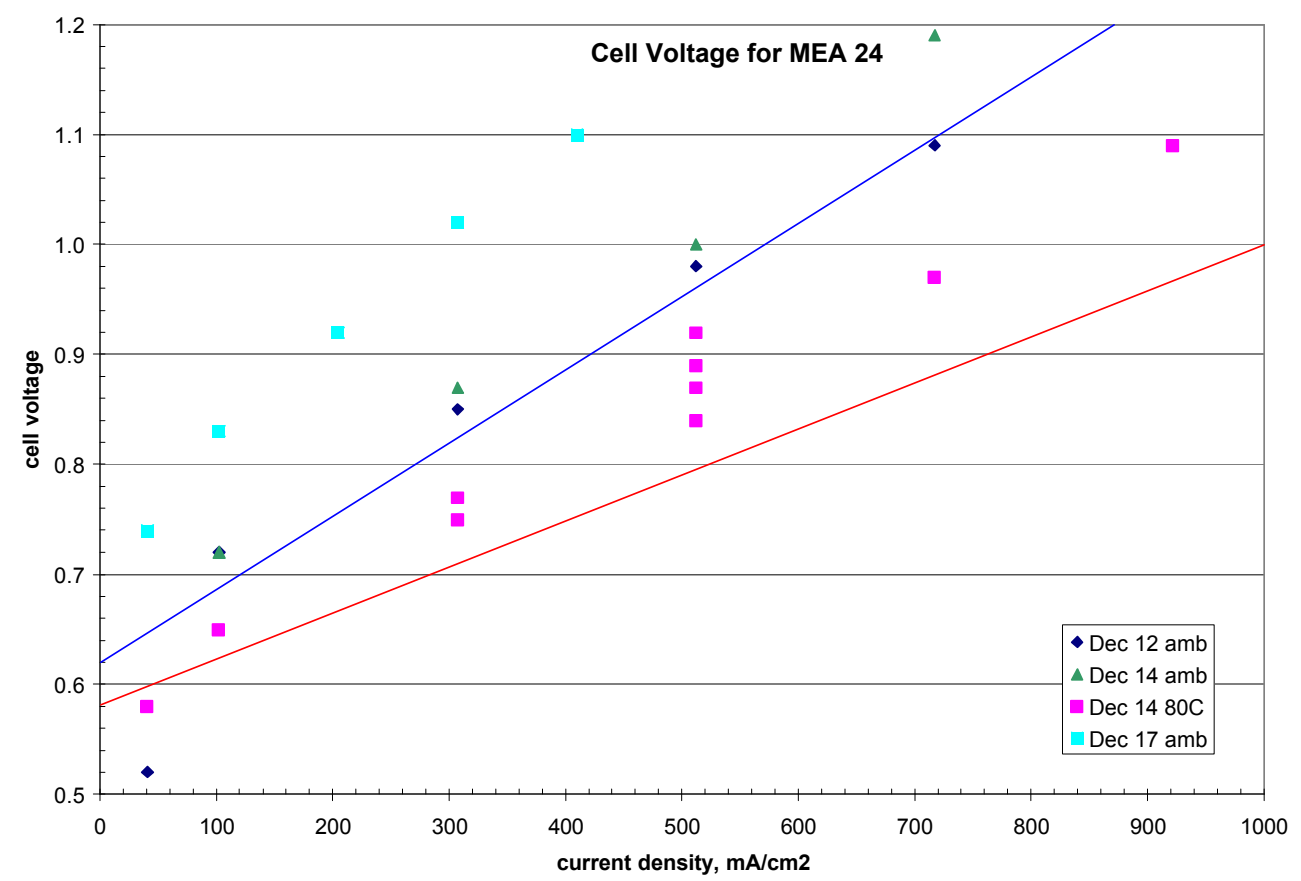

Figure 8 Cell Voltage for MEA 24

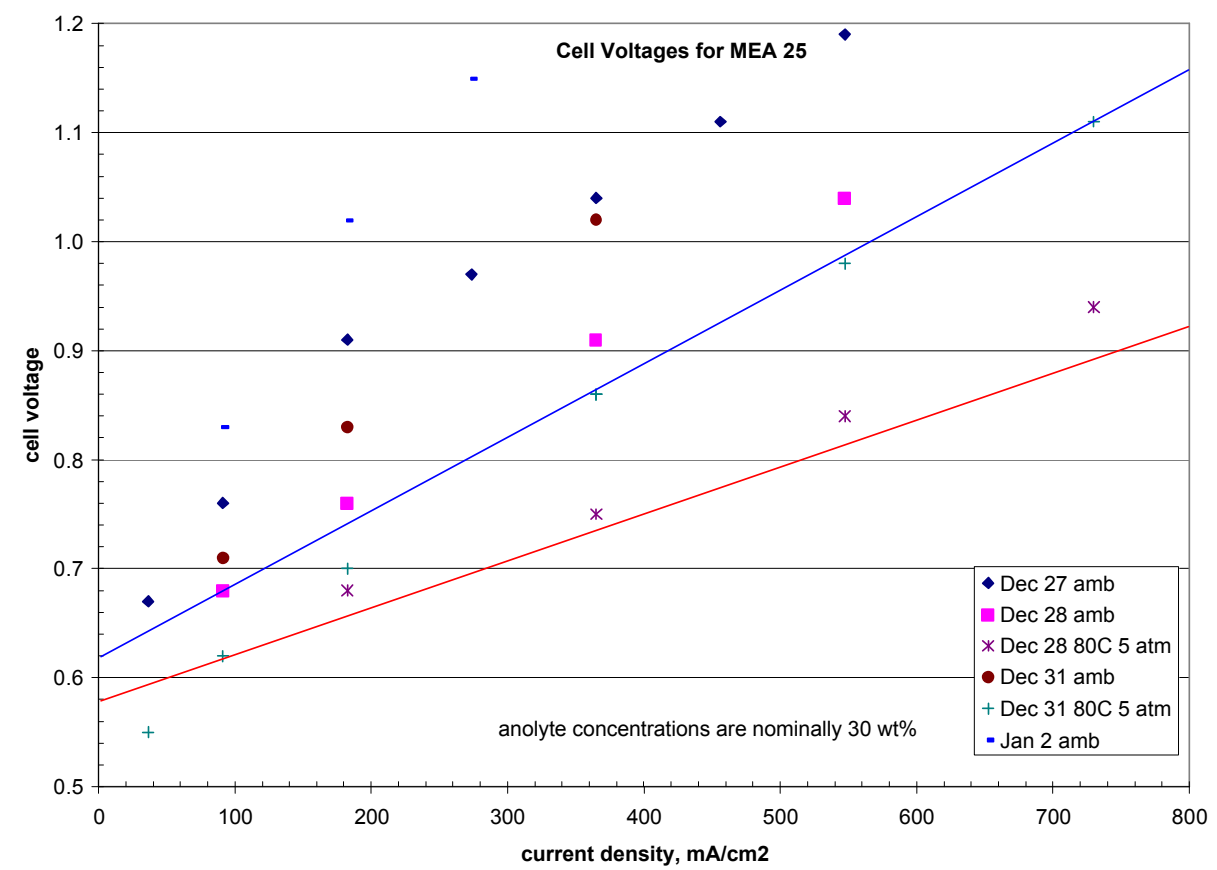

Figure 9 Cell Voltage for MEA 25 


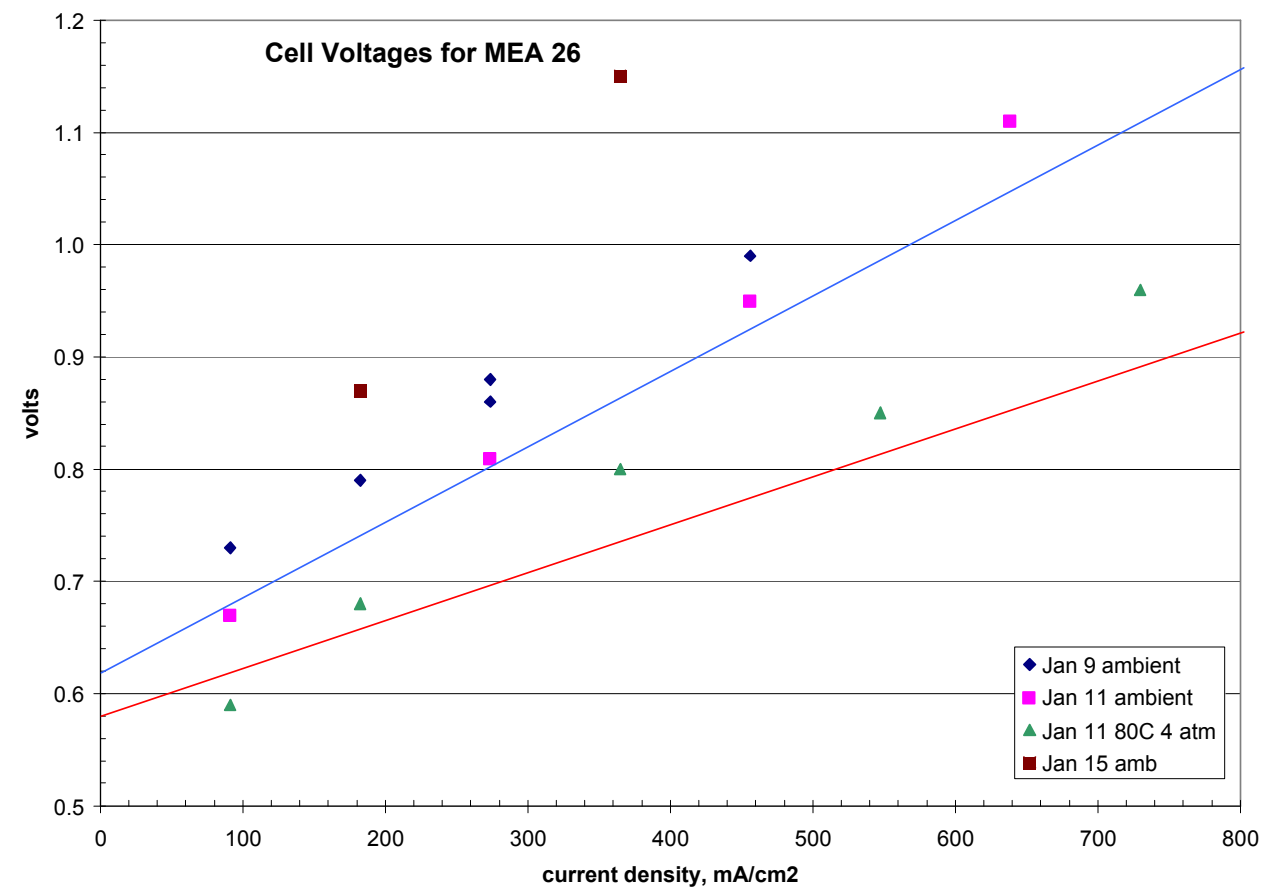

Figure 10 Cell Voltage for MEA 26

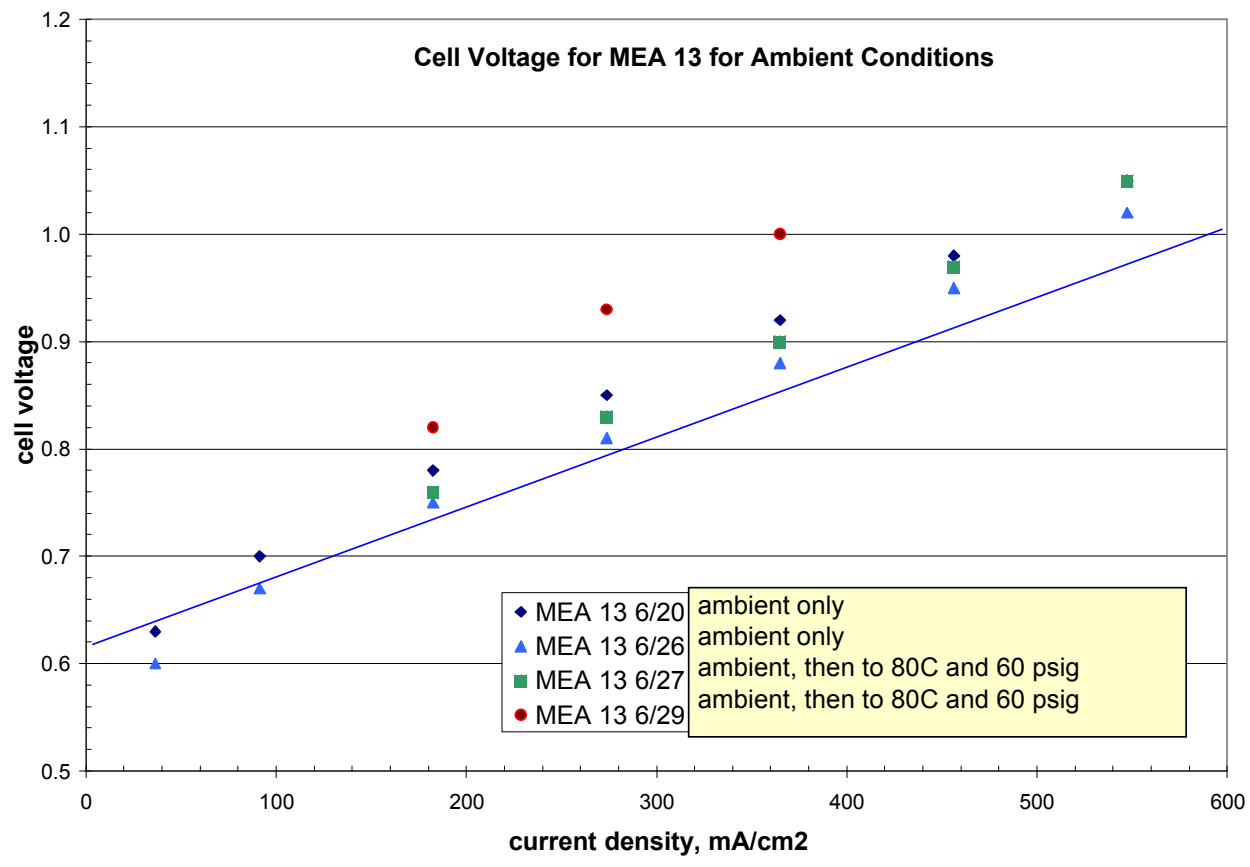

Figure 11 Cell Voltage for MEA 13 


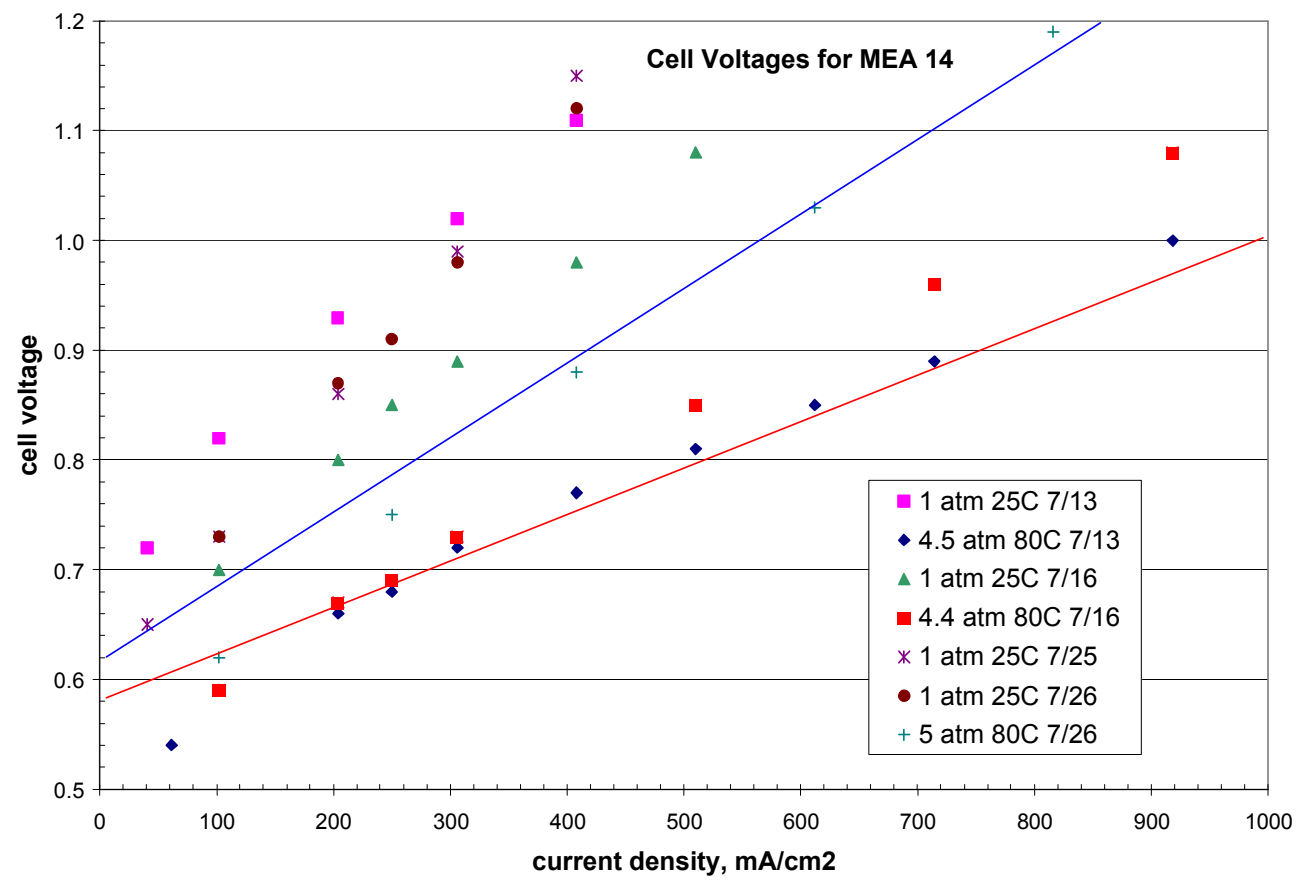

\section{Figure 12 Cell Voltage for MEA 14}

\subsubsection{Anolyte Flow and Pressure Drop}

Figure 13 plots the cell pressure drop for anolyte flow for MEA 25, a typical result. The pressure drop increased at 1.2 hours when the $\mathrm{SO}_{2}$ pressure and thus concentration in the anolyte increased. The pressure drop decreased from 1.4 hours to 2.4 hours as the anolyte was heated which reduced its viscosity. 


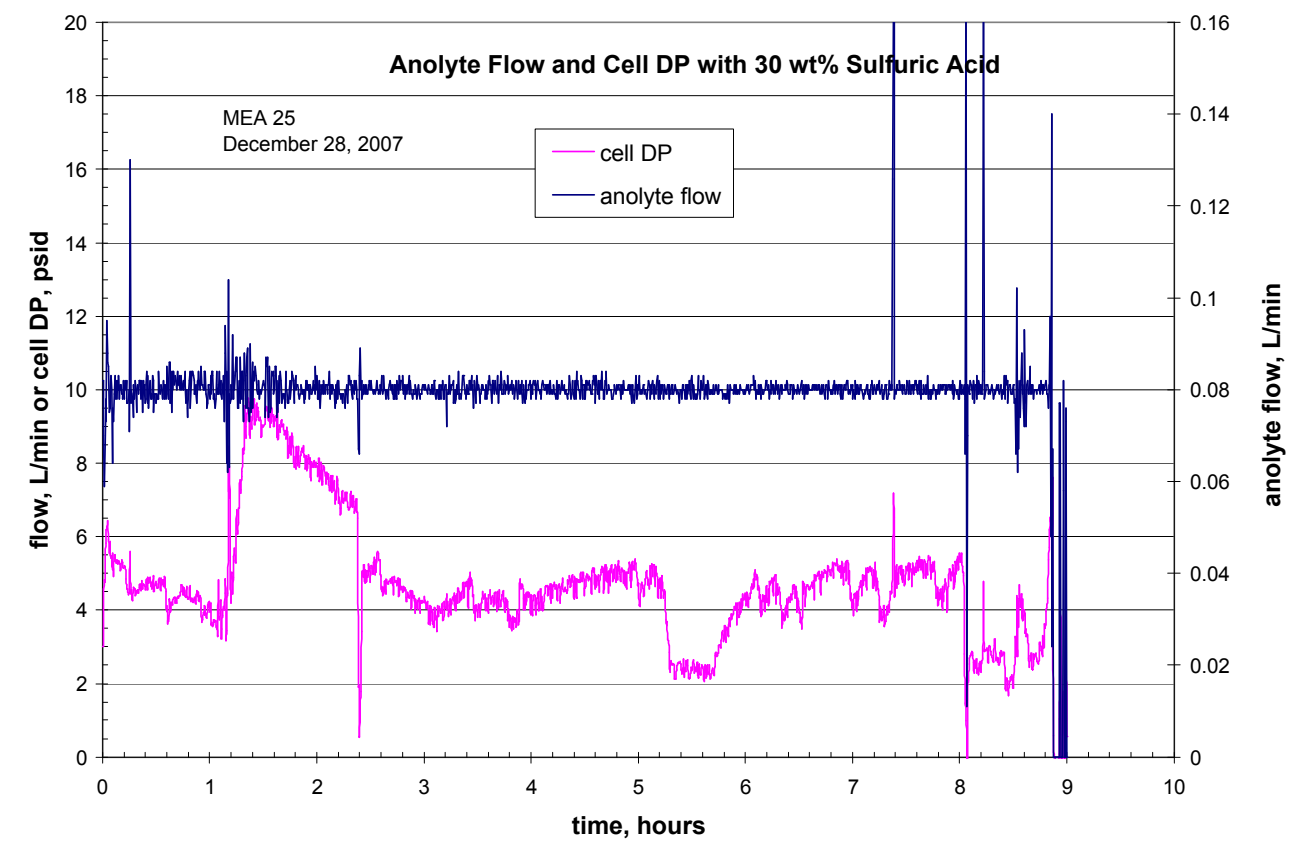

Figure 13 Anolyte Flow and Pressure Drop

\subsubsection{Hydrogen Production}

Figure 14 plots typical hydrogen generation rates for MEA 25. The theoretical generation rate is proportional to current, because each mole of hydrogen requires two Faradays of electrons. Data points are plotted for the two methods of hydrogen measurement. The production rate was nearly the same as theoretical. 


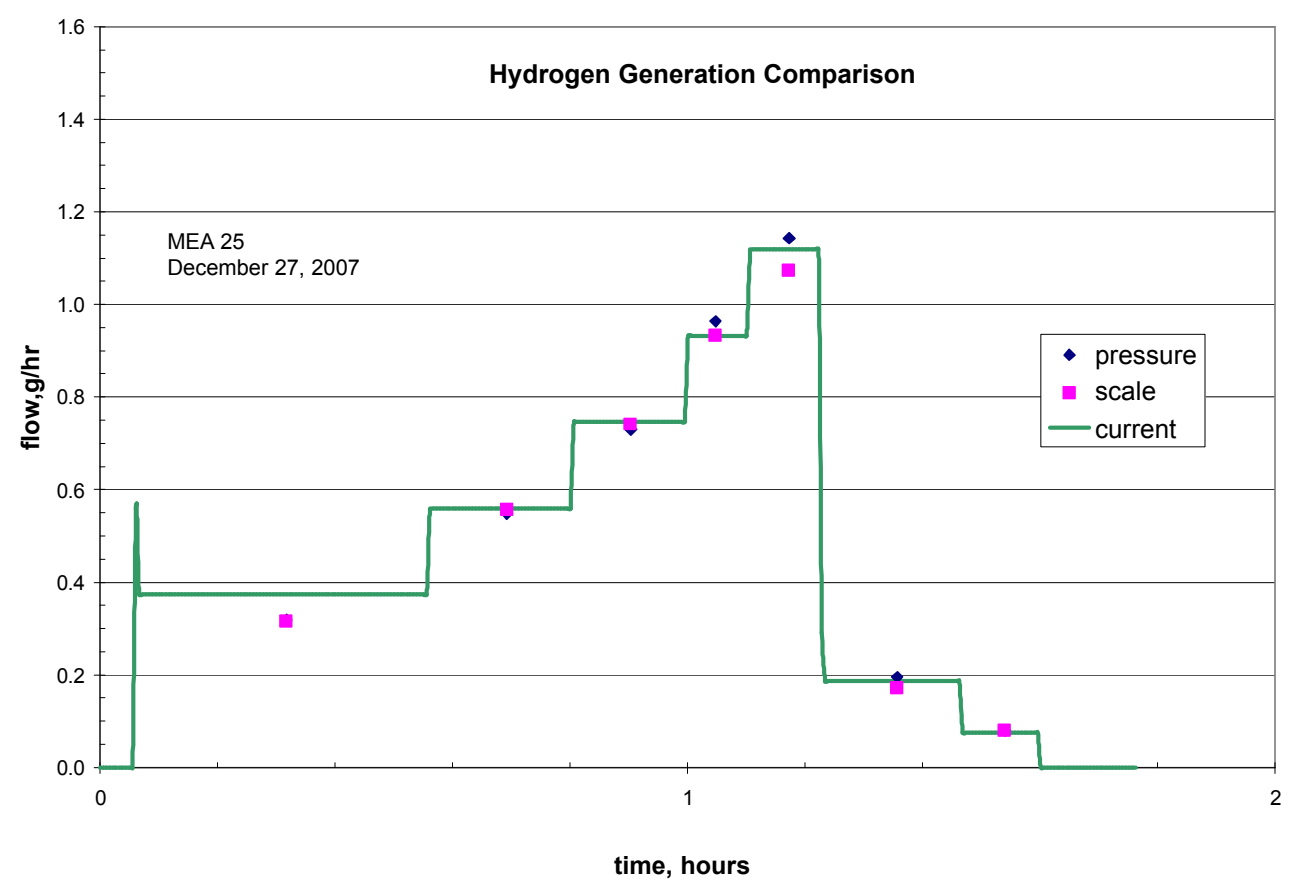

Figure 14 Hydrogen Production Rate

\subsubsection{Post-Test Examinations of MEA}

Samples from ten MEA were examined under scanning electron microscope (SEM), which can identify elemental composition. MEA 4, MEA 10, MEA 12, MEA 13, MEA 14, MEA 20, MEA 25 and MEA 26 all formed sulfur layers between the membrane and the cathode. Only MEA 9 did not form a sulfur layer. It is not yet known why MEA 9 was different. Investigation of the reasons for formation of this layer will continue. The SEM of MEA 20, which is typical, is shown in Figure 14. The sulfur layer is almost as thick as the membrane, about 5 mils. The sulfur layer is expected to hinder passage of protons and to increase cell voltage. 


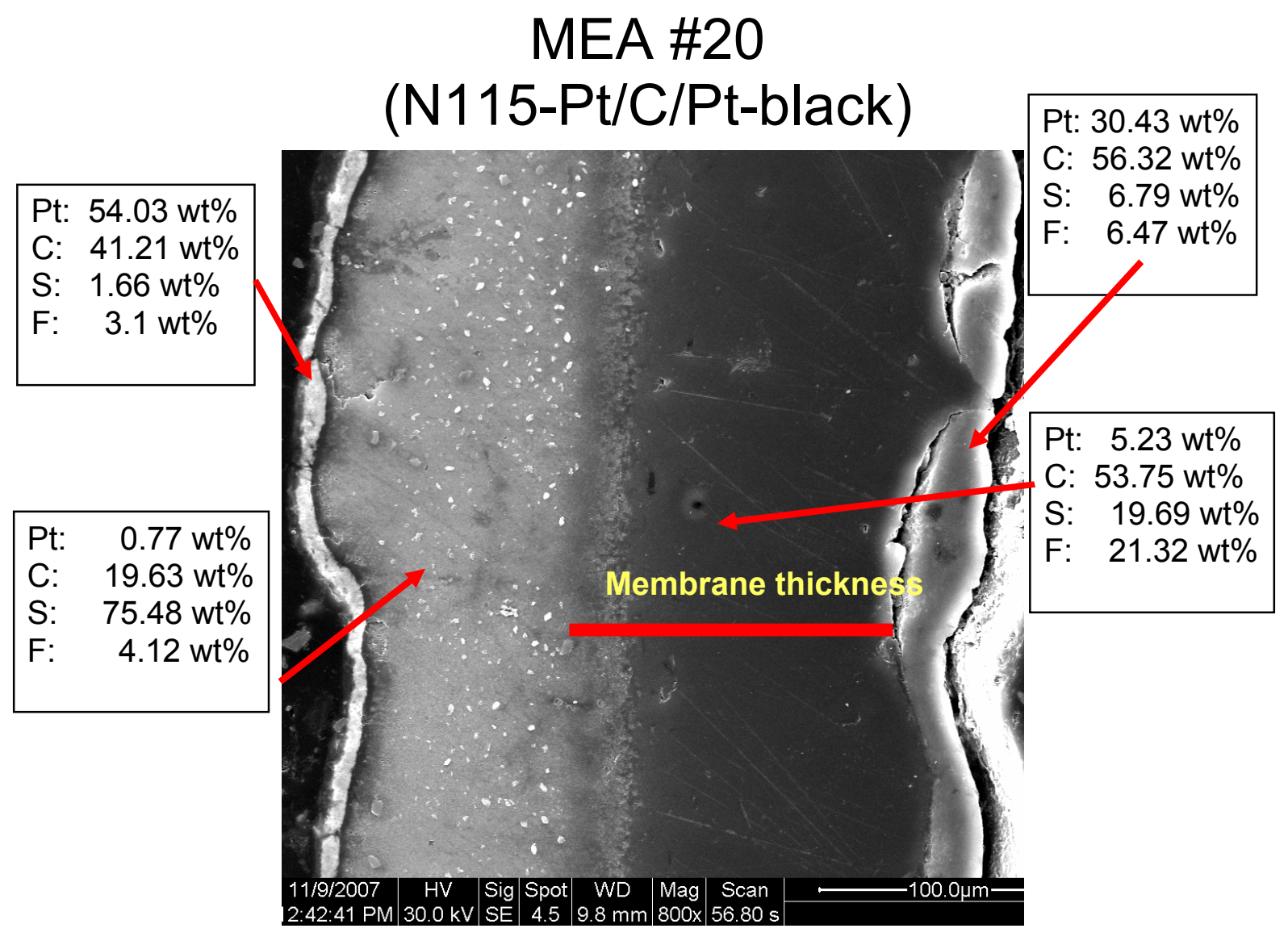

Figure 15 SEM of MEA 20 


\subsection{CONCLUSIONS}

The primary observations resulting from this work are as follows.

1. The electrolyzer demonstrated a high current efficiency for hydrogen production.

2. All else held constant, cell voltage is a nearly linear function of current density.

3. Increasing temperature and pressure to $80^{\circ} \mathrm{C}$ and 4 to 6 atm substantially decrease cell voltage.

4. Running at ambient conditions does not seem to cause an increase in cell voltage with time. Running at elevated temperature and pressure seems to cause an increase in cell voltage with time.

5. Some of the MEA tested in this facility were subsequently examined by scanning electron microscopy. With the exception of MEA 9, which was run only briefly at elevated temperature and pressure, all had formed a sulfur layer between the membrane and cathode. It is concluded that the sulfur layer caused the increase in cell voltage.

6. The MEA with platinum impregnated membranes were mechanically weak and did not last.

\subsection{FUTURE WORK}

1. Using the insights gained on the formation of sulfur in the MEA, future work will emphasize solution of this problem.

2. After the work reported here was completed, a three cell electrolyzer stack built by the Giner Company was tested. A report will be issued that describes that testing. Then testing will resume on the stack which was rebuilt with new MEAs.

3. Testing of various types of MEA will continue. This will include the advanced membrane types that have been characterized during the Component Development task of this program, including hydrocarbon-based membranes being developed by Sandia National Laboratory and others. One of the goals will be to reduce or eliminate $\mathrm{SO}_{2}$ crossover.

4. SRNL will pursue means to permit unattended operation for the electrolyzer facility to allow longer continuous run times. This will involve the following issues.

i) How to remove excess anolyte automatically.

ii) How to remove contents of Sulfur Collector automatically.

iii) How to recharge the water syringe pump and the sulfur dioxide syringe pump, automatically.

iv) How to make up the inventory of the bath heater to accommodate evaporation.

v) Locate an instrument that can continuously monitor anolyte density and use this information to control addition of water to the anolyte. (Currently we remove a sample, measure density and adjust flowrate. The instrument must be corrosion resistant, tolerate the temperature and pressure and not require much anolyte volume.

vi) How to program the control computer to respond to any upset condition.

\subsection{ACKNOWLEDGEMENTS}

Bill Summers served as Program Manager for this work. Hector Colon-Mercado prepared some of the MEA and made Scanning Electrons Micrographs of the MEA after the test. 


\subsection{REFERENCES}

Colon-Mercado, H. R., D. T. Hobbs, D. B. Coleman and A. A. Ekechukwu, "Initial Component Test Results for an $\mathrm{SO}_{2}$ Depolarized Electrolyzer Cell Design, WSRC-STI-2006-00064, August 2006.

DOE Hydrogen Posture Plan, February 2004. www.eere.energy.gov/hydrogenandfuelcells

Ephraim, Fritz, 1954, Inorganic Chemistry, $6^{\text {th }}$ edition.

Farbman, G. H., 1976, "The Conceptual Design of an Integrated Nuclear Hydrogen Production Plant Using the Sulfur Cycle Water Decomposition System, NASA Contractor Report, NASA-CR-134976.

Kirk-Othmer, 1991, Encylopedia of Chemical Technology, Fourth Edition, article on Hydrogen.

Lu, P. W. T., and R. L. Ammon, 1980, “An Investigation of Electrode Materials for the Anodic Oxidation of Sulfur Dioxide in Concentrated Sulfuric Acid”, J. Electrochem. Soc.: Electrochemical Science and Technology, Vol. 127, No. 12, pp. 2610-2616, December.

Lu, P. W. T., E. R. Garcia and R. L. Ammon, 1981, "Recent Developments in the Technology of Sulhur Dioxide Depolarized Electrolysis", J. of Appl. Electrochem., Vol. 11, pp. 347-355.

Lu, P. W. T., and R. L. Ammon, 1982, "Sulfur Dioxide Depolarized Electrolysis for Hydrogen Production: Development Status", Int. J. Hydrogen Energy, Vol. 7, No. 7, pp. 563-575.

Lu, P. W. T., 1983, "Technological Aspects of Sulfur Dioxide Depolarized Electrolysis for Hydrogen Production”, Int. J. Hydrogen Energy, Vol. 8, No. 10, pp. 773-781.

G. H. Parker, 1982, "Solar Thermal Hydrogen Production Process", Westinghouse Electric Corporation, DOE/ET/20608-1.

Steimke, J. L. and T. J. Steeper, "Characterization Testing of $\mathrm{H}_{2} \mathrm{O}-\mathrm{SO}_{2}$ Electrolyzer at Ambient Pressure”, WSRC-TR-2005-00310, Rev. 0, August 2005.

Steimke, J. L. and T. J. Steeper, "Characterization Testing and Analysis of Single Cell $\mathrm{SO}_{2}$ Depolarized Electrolyzer”, WSRC-STI-2006-00120, Rev. 1, September 2006.

Steimke, J. L. and T. J. Steeper, "Single Cell SO2-Depolarized Electrolyzer Longevity Test Results”, WSRC-STI-2007-00300, June 2007.

Subbaiah, T., P. Singh, G. Hefter, D. Muir and R. P. Das, 2000, "Sulphurous acid as anodic depolarizer in copper electrowinning”, J. Applied Electrochemistry, vol. 30, pp.181-186.

Weidner, J. W., 2005, "Electrochemical Generation of Hydrogen via Thermochemical Cycles", AIChE Spring National Meeting, Atlanta, April 12.

Westinghouse Electric Corporation, 1980, "A Study on the Electrolysis of Sulfur Dioxide and Water for the Sulfur Cycle Hydrogen Production Process", AESD-TME-3043, July. 
SINGLE CELL STACK ELECTROLYZER TEST RESULTS

WSRC-STI-2008-00231

Table 2 Summary of MEA Characteristics in Single Cell Tests

\begin{tabular}{|c|c|c|c|c|c|c|c|}
\hline $\begin{array}{c}\text { MEA } \\
\#\end{array}$ & Membrane & $\begin{array}{l}\text { Membrane } \\
\text { thickness, } \\
\text { mils }\end{array}$ & $\begin{array}{c}\text { Anode } \\
\text { flow field }\end{array}$ & $\begin{array}{l}\text { Cathode } \\
\text { flow field }\end{array}$ & $\begin{array}{l}\text { Anode } \\
\text { Pt } \\
\text { loading, } \\
\text { mg/cm2 }\end{array}$ & $\begin{array}{c}\text { Cathode } \\
\mathrm{Pt} \\
\text { loading, } \\
\mathrm{mg} / \mathrm{cm} 2\end{array}$ & $\begin{array}{l}\text { Active } \\
\text { area, } \\
\mathrm{cm} 2\end{array}$ \\
\hline 1 & Nafion-115 & 5 & E-Tek & E-Tek & $\begin{array}{l}0.65 \\
\text { Pt-C }\end{array}$ & $\begin{array}{l}0.65 \\
\text { Pt-C }\end{array}$ & 49.0 \\
\hline 2 & Nafion-117 & 7 & $\begin{array}{l}\text { Carbon } \\
\text { paper, } 7 \\
\text { mil }\end{array}$ & $\begin{array}{l}\text { Carbon } \\
\text { cloth, } 12 \\
\text { mils }\end{array}$ & $\begin{array}{l}1.13 \\
\mathrm{Pt}-\mathrm{C}\end{array}$ & $\begin{array}{l}1.14 \\
\text { Pt-C }\end{array}$ & 49.7 \\
\hline 3 & Nafion-117 & 7 & $\begin{array}{c}\text { Carbon } \\
\text { paper, } 7 \\
\text { mil }\end{array}$ & $\begin{array}{c}\text { Carbon } \\
\text { cloth, } 12 \\
\text { mils } \\
\end{array}$ & $\begin{array}{l}1.44 \\
\text { Pt-C }\end{array}$ & $\begin{array}{l}1.32 \\
\text { Pt-C }\end{array}$ & 48.1 \\
\hline 4 & Nafion-117 & 7 & $\begin{array}{c}\text { Carbon } \\
\text { paper, } 7 \\
\text { mil }\end{array}$ & $\begin{array}{c}\text { Carbon } \\
\text { cloth, } 12 \\
\text { mils } \\
\end{array}$ & $\begin{array}{l}0.88 \\
\text { Pt-C }\end{array}$ & $\begin{array}{l}0.99 \\
\text { Pt-C }\end{array}$ & 49.7 \\
\hline 5 & Celtec-L & 4 & $\begin{array}{c}\text { Carbon } \\
\text { paper, } 7 \\
\text { mil }\end{array}$ & $\begin{array}{l}\text { Carbon } \\
\text { cloth, } 12 \\
\text { mils }\end{array}$ & $\begin{array}{c}1.0 \\
\mathrm{Pt}-\mathrm{C}\end{array}$ & $\begin{array}{c}1.0 \\
\text { Pt-C }\end{array}$ & 46.3 \\
\hline 6 & $\begin{array}{l}\text { Celtec-L } \\
2 \text { layers }\end{array}$ & 8 & $\begin{array}{c}\text { Carbon } \\
\text { paper, } 7 \\
\text { mil }\end{array}$ & $\begin{array}{l}\text { Carbon } \\
\text { cloth, } 12 \\
\text { mils }\end{array}$ & $\begin{array}{l}1.47 \\
\text { Pt-C }\end{array}$ & $\begin{array}{l}2.16 \\
\text { Pt-C }\end{array}$ & 49.7 \\
\hline 7 & Celtec-V & 4 & $\begin{array}{c}\text { Carbon } \\
\text { paper, } 7 \\
\text { mil }\end{array}$ & $\begin{array}{c}\text { Carbon } \\
\text { cloth, } 12 \\
\text { mils } \\
\end{array}$ & $\begin{array}{c}0.8 \\
\text { Pt-C }\end{array}$ & $\begin{array}{c}0.8 \\
\text { Pt-C }\end{array}$ & 47 \\
\hline 8 & Nafion-115 & 5 & $\begin{array}{c}\text { Carbon } \\
\text { paper, } 7 \\
\text { mil }\end{array}$ & $\begin{array}{l}\text { Carbon } \\
\text { cloth, } 12 \\
\text { mils }\end{array}$ & $\begin{array}{l}0.78 \\
\text { Pt-C }\end{array}$ & $\begin{array}{l}0.61 \\
\text { Pt-C }\end{array}$ & 49.7 \\
\hline 9 & $\begin{array}{l}\text { Nafion-117 } \\
\text { Giner }\end{array}$ & 7 & $\begin{array}{c}\text { Carbon } \\
\text { paper, } 7 \\
\text { mil }\end{array}$ & $\begin{array}{l}\text { Carbon } \\
\text { cloth, } 12 \\
\text { mils }\end{array}$ & $\begin{array}{c}4.0 \\
\text { Pt black }\end{array}$ & $\begin{array}{c}4.0 \\
\text { Pt black }\end{array}$ & 49.7 \\
\hline 10 & $\begin{array}{c}\text { Nafion-117 } \\
\text { Giner }\end{array}$ & 7 & $\begin{array}{c}\text { Carbon } \\
\text { paper, } 7 \\
\text { mil }\end{array}$ & $\begin{array}{c}\text { Carbon } \\
\text { cloth, } 12 \\
\text { mils }\end{array}$ & $\begin{array}{c}1.0 \\
\text { Pt-C }\end{array}$ & $\begin{array}{c}1.0 \\
\text { Pt-C }\end{array}$ & 49.7 \\
\hline 11 & Nafion-115 & 5 & $\begin{array}{c}\text { Carbon } \\
\text { paper, } 7 \\
\text { mil }\end{array}$ & $\begin{array}{c}\text { Carbon } \\
\text { cloth, } 12 \\
\text { mils }\end{array}$ & $\begin{array}{l}1.09 \\
\text { Pt-C }\end{array}$ & $\begin{array}{l}0.72 \\
\text { Pt-C }\end{array}$ & $\begin{array}{l}47.6 \\
\text { and } \\
54.8\end{array}$ \\
\hline 12 & Nafion-115 & 5 & $\begin{array}{c}\text { Carbon } \\
\text { paper, } 7 \\
\text { mil }\end{array}$ & $\begin{array}{l}\text { Carbon } \\
\text { cloth, } 12 \\
\text { mils }\end{array}$ & $\begin{array}{l}1.01 \\
\text { Pt-C }\end{array}$ & $\begin{array}{l}1.01 \\
\text { Pt-C }\end{array}$ & 54.8 \\
\hline 13 & Nafion-115 & 5 & $\begin{array}{c}\text { Carbon } \\
\text { paper, } 7 \\
\text { mil }\end{array}$ & $\begin{array}{c}\text { Carbon } \\
\text { cloth, } 12 \\
\text { mils } \\
\end{array}$ & $\begin{array}{l}1.02 \\
\text { Pt-C }\end{array}$ & $\begin{array}{l}0.59 \\
\text { Pt-C }\end{array}$ & 54.8 \\
\hline 14 & $\begin{array}{l}\text { Nafion-117 } \\
\text { Giner }\end{array}$ & 7 & $\begin{array}{c}\text { Carbon } \\
\text { paper, } 7 \\
\text { mil }\end{array}$ & $\begin{array}{l}\text { Carbon } \\
\text { cloth, } 12 \\
\text { mils }\end{array}$ & $\begin{array}{c}0.8 \\
\text { Pt-C }\end{array}$ & $\begin{array}{c}0.8 \\
\text { Pt-C }\end{array}$ & 49 \\
\hline 15 & $\begin{array}{c}\text { polyphenylene } \\
\text { SDAPP } 2.2 \\
\text { Hickner }\end{array}$ & 2 & $\begin{array}{c}\text { Carbon } \\
\text { paper, } 7 \\
\text { mil }\end{array}$ & $\begin{array}{c}\text { Carbon } \\
\text { cloth, } 12 \\
\text { mils }\end{array}$ & $\begin{array}{c}1.5 \\
\text { Pt black }\end{array}$ & $\begin{array}{c}1.5 \\
\text { Pt black }\end{array}$ & 46.3 \\
\hline
\end{tabular}


SINGLE CELL STACK ELECTROLYZER TEST RESULTS

WSRC-STI-2008-00231

\begin{tabular}{|c|c|c|c|c|c|c|c|}
\hline 16 & $\begin{array}{c}\text { polyphenylene } \\
\text { SDAPP } 2.2 \\
\text { Hickner }\end{array}$ & 2 & $\begin{array}{c}\text { Carbon } \\
\text { paper, } 7 \\
\text { mil }\end{array}$ & $\begin{array}{l}\text { Carbon } \\
\text { cloth, } 12 \\
\text { mils }\end{array}$ & $\begin{array}{c}1.5 \\
\mathrm{Pt}-\mathrm{C}\end{array}$ & $\begin{array}{c}1.5 \\
\text { Pt-C }\end{array}$ & 54.8 \\
\hline 17 & $\begin{array}{c}\text { Nafion-212 } \\
\text { Lynntech }\end{array}$ & 2 & $\begin{array}{c}\text { Carbon } \\
\text { paper, } 7 \\
\text { mil }\end{array}$ & $\begin{array}{c}\text { Carbon } \\
\text { cloth, } 12 \\
\text { mils } \\
\end{array}$ & $\begin{array}{c}1.5 \\
\text { Pt black }\end{array}$ & $\begin{array}{c}1.5 \\
\text { Pt black }\end{array}$ & 50. \\
\hline 18 & Nafion-115 & 5 & $\begin{array}{c}\text { Carbon } \\
\text { paper, } 7 \\
\text { mil }\end{array}$ & $\begin{array}{c}\text { Carbon } \\
\text { cloth, } 12 \\
\text { mils }\end{array}$ & $\begin{array}{l}0.75 \\
\text { Pt-C }\end{array}$ & $\begin{array}{l}0.75 \\
\mathrm{Pt}-\mathrm{C}\end{array}$ & 54.8 \\
\hline 19 & Nafion-115 & 5 & $\begin{array}{c}\text { Carbon } \\
\text { paper, } 7 \\
\text { mil }\end{array}$ & $\begin{array}{l}\text { Carbon } \\
\text { cloth, } 12 \\
\text { mils }\end{array}$ & $\begin{array}{l}0.83 \\
\mathrm{Pt}-\mathrm{C}\end{array}$ & $\begin{array}{c}0.7 \\
\text { Pt-C }\end{array}$ & 54.8 \\
\hline 20 & Nafion-115 & 5 & $\begin{array}{c}\text { Carbon } \\
\text { paper, } 7 \\
\text { mil }\end{array}$ & $\begin{array}{c}\text { Carbon } \\
\text { cloth, } 12 \\
\text { mils } \\
\end{array}$ & $\begin{array}{l}0.782 \\
\text { Pt-C }\end{array}$ & $\begin{array}{c}2.67 \\
\text { Pt black }\end{array}$ & 54.8 \\
\hline 21 & Nafion-115 & 5 & $\begin{array}{c}\text { Carbon } \\
\text { paper, } 7 \\
\text { mil }\end{array}$ & $\begin{array}{c}\text { Carbon } \\
\text { cloth, } 12 \\
\text { mils }\end{array}$ & $\begin{array}{c}0.6 \\
\text { Pt-C }\end{array}$ & $\begin{array}{c}2.9 \\
\text { Pt black }\end{array}$ & 54.8 \\
\hline 22 & $\begin{array}{c}\text { Nafion } 117 \\
\text { Pt impregn. } \\
\text { Giner } \\
\end{array}$ & 7 & $\begin{array}{c}\text { Carbon } \\
\text { paper, } 7 \\
\text { mil }\end{array}$ & $\begin{array}{l}\text { Carbon } \\
\text { cloth, } 12 \\
\text { mils }\end{array}$ & $\begin{array}{c}1.0 \\
\text { Pt black }\end{array}$ & $\begin{array}{c}1.0 \\
\text { Pt black }\end{array}$ & 54.8 \\
\hline 23 & $\begin{array}{c}\text { Nafion } 117 \\
\text { Pt impregn. } \\
\text { Giner } \\
\end{array}$ & 7 & $\begin{array}{c}\text { Carbon } \\
\text { paper, } 7 \\
\text { mil }\end{array}$ & $\begin{array}{c}\text { Carbon } \\
\text { cloth, } 12 \\
\text { mils } \\
\end{array}$ & $\begin{array}{c}1.0 \\
\text { Pt-C }\end{array}$ & $\begin{array}{c}1.0 \\
\text { Pt black }\end{array}$ & 54.8 \\
\hline 24 & $\begin{array}{c}\text { Nafion } 117 \\
\text { Pt impregn. } \\
\text { Giner }\end{array}$ & 7 & $\begin{array}{c}\text { Carbon } \\
\text { paper, } 7 \\
\text { mil }\end{array}$ & $\begin{array}{c}\text { Carbon } \\
\text { cloth, } 12 \\
\text { mils }\end{array}$ & $\begin{array}{c}1.0 \\
\text { Pt-C }\end{array}$ & $\begin{array}{c}1.0 \\
\text { Pt black }\end{array}$ & 48.8 \\
\hline 25 & $\begin{array}{l}\text { Nafion } 117 \\
\text { Giner }\end{array}$ & 7 & $\begin{array}{c}\text { Carbon } \\
\text { paper, } 7 \\
\text { mil }\end{array}$ & $\begin{array}{l}\text { Carbon } \\
\text { cloth, } 12 \\
\text { mils }\end{array}$ & $\begin{array}{c}4.0 \\
\text { Pt black }\end{array}$ & $\begin{array}{c}4.0 \\
\text { Pt black }\end{array}$ & 54.8 \\
\hline 26 & $\begin{array}{l}\text { Nafion } 117 \\
\text { Giner }\end{array}$ & 7 & $\begin{array}{c}\text { Carbon } \\
\text { paper, } 7 \\
\text { mil }\end{array}$ & $\begin{array}{c}\text { Carbon } \\
\text { cloth, } 12 \\
\text { mils } \\
\end{array}$ & $\begin{array}{c}4.0 \\
\text { Pt black }\end{array}$ & $\begin{array}{c}4.0 \\
\text { Pt black }\end{array}$ & 54.8 \\
\hline
\end{tabular}

